MAYSA DE SÁ PITTONDO DELIGNE

\title{
EFEITOS DAS DECISÕES NO PROCESSO ADMINISTRATIVO TRIBUTÁRIO
}

Tese de Doutorado

Orientador: Professor Titular Dr. Humberto Bergmann Ávila

UNIVERSIDADE DE SÃO PAULO

FACULDADE DE DIREITO

São Paulo - SP

2020 



\section{EFEITOS DAS DECISÕES NO PROCESSO ADMINISTRATIVO TRIBUTÁRIO}

Tese apresentada à Banca Examinadora do Programa de Pós-Graduação em Direito, da Faculdade de Direito da Universidade de São Paulo, como exigência parcial para obtenção do título de Doutora em Direito, na área de concentração Direito Econômico, Financeiro e Tributário, sob a orientação do Prof. Titular Dr. Humberto Bergmann Ávila.

\section{UNIVERSIDADE DE SÃO PAULO}

\section{FACULDADE DE DIREITO}

São Paulo - SP 
Autorizo a reprodução e divulgação parcial deste trabalho, por qualquer meio convencional ou eletrônico, para fins de estudo e pesquisa, desde que citada a fonte.

Deligne, Maysa de Sá Pittondo

Efeitos das decisões no processo administrativo

tributário; Maysa de Sá Pittondo Deligne ;

orientador Humberto Bergmann Ávila -- Sấ Paulo, 2020 .

$216 \mathrm{f}$.

Tese (Doutorado - Programa de Pós-Graduação em Direito Direito Econômico, Financeiro e Tributário) Faculdade de Direito, Universidade de São Paulo, 2020 .

1. Direito tributário. 2. Processo administrativo tributário. 3. Jurisdição. 4. Eficácia. 5. Estabilidade das decisốes administrativas tributárias. I. Ávila, Humberto Bergmann, orient. I. Título. 


\section{AGRADECIMENTOS}

Sacrifícios são inerentes à originalidade exigida de uma tese de doutorado, em especial cursado nesta Faculdade de Direito do Largo São Francisco. Incontáveis horas de estudo, regulares viagens de Belo Horizonte/Brasília a São Paulo para participar das disciplinas e das monitorias da Graduação, ausências nos encontros com a família e amigos. Mas ainda que possa ser um caminho muitas vezes solitário, tive a grande sorte de estar acompanhada de pessoas extraordinárias.

Primeiramente, agradeço ao Professor Titular Dr. Humberto Ávila pela oportunidade de ingressar no Programa de doutorado, de acompanhar suas aulas de Graduação e participar das monitorias. Obrigada pelas lições dadas nas aulas da PósGraduação e pela orientação.

Agradeço ao Professor Titular Dr. Luís Eduardo Schoueri pelos muitos ensinamentos desde o mestrado e pelas críticas e considerações feitas na banca de qualificação juntamente com o Professor Titular Dr. Flávio Luiz Yarshell, a quem igualmente agradeço pela atenta leitura daquela proposta de pesquisa e pelos comentários na perspectiva do Direito Processual. Cada observação, crítica e ponderação feita naquela oportunidade auxiliou sobremaneira a elaboração deste trabalho. Obrigada ainda aos Professores Dr. Paulo Ayres Barreto (inclusive pela confiança para ingressar nesta Faculdade), Dr. Pasquale Pistone, Dr. João Félix Nogueira, Dr. José Reinaldo de Lima Lopes, Dr. Paulo Henrique dos Santos Lucon, Dra. Susana Henriques da Costa, pelo conhecimento compartilhado nas disciplinas cursadas no doutorado.

Aos meus mestres e amigos da Associação Brasileira de Direito Tributário (ABRADT), meu mais sincero agradecimento pela paciência em debater minha pesquisa em qualquer oportunidade. Agradeço em especial aos amigos e Professores Dr. Valter Lobato e Dr. André Mendes Moreira, pelo constante apoio e incentivo nas horas mais difíceis. Agradeço ainda ao Professor André pela confiança para apresentar algumas considerações sobre o processo administrativo tributário na Faculdade de Direito da Universidade Federal de Minas Gerais (UFMG), retornando a minha casa de origem da Graduação.

Agradeço ao Professor Dr. Sérgio André Rocha pela paciência em buscar organizar minhas ideias sobre o processo administrativo tributário no Congresso da ABRADT, bem como pela amizade e constantes auxílios e debates. Agradeço também ao Professor Maurício Faro por oportunizar o debate das premissas desta pesquisa no Seminário 
Processo Administrativo Tributário em Discussão, na OAB/RJ, e ao Professor Ricardo Maitto pelo convite para expor algumas de minhas reflexões sobre o processo administrativo tributário no tradicional curso de introdução do Instituto Brasileiro de Direito Tributário (IBDT).

Faço um agradecimento especial ao Professor Guillermo Teijeiro, pela amizade e auxílio para conhecer o Tribunal Fiscal de la Nación Argentina e propiciar a reunião com o Dr. Pablo Porporatto, juiz daquele Tribunal, e sua secretária Dra. Juliana Paccini, a quem agradeço pela disponibilidade para exporem e esclarecerem o contencioso administrativo tributário daquele país.

Sou profundamente grata aos meus amigos do mestrado e do Conselho Administrativo de Recursos Fiscais (CARF) pela paciência e pelas preciosas críticas feitas no curso desta pesquisa, em especial: Thais De Laurentiis, Diego Diniz Ribeiro, Carlos Augusto Daniel Neto, Salvador Cândido Brandão Junior, Rita Eliza Reis da Costa, Júnia Roberta Gouveia Sampaio, Martha Leão e Vanessa Grazziotin Dexheimer. Muito obrigada pelos constantes debates que fizeram esta pesquisa tomar a forma de proposta de tese. Agradeço particularmente ao Diego e à Martha por tirarem um tempo de suas agendas concorridas para fazerem considerações sobre a minuta deste trabalho.

Agradeço aos meus amigos feitos ao longo do doutorado, que muito debateram comigo minha pesquisa, quando ainda estava sem rumo: Daniela Dias, João Alho Neto, Pedro Ribas, Paulo Arthur Koury, Eduardo Halperin e, especial, Clara Moreira. Obrigada pela companhia, pela amizade e por me apresentarem autores que foram imprescindíveis para este trabalho.

Agradeço ainda aos funcionários das bibliotecas que muito me ajudaram na pesquisa, em especial da Biblioteca do IBDT, da Biblioteca Nazionale Centrale di Roma, da Biblioteca del Senato della Repubblica Italiana e da Biblioteca do Superior Tribunal de Justiça. Na reta final deste trabalho, agradeço à Lília Finelli pela criteriosa correção ortográfica e de formatação.

E tudo isso não seria possível sem a minha família e amigos. Agradeço muito aos meus pais Silvio e Rúbia pela paciência, pelo apoio incondicional e pelas comemorações das pequenas conquistas. Minha irmã Marina por me dar um lar em São Paulo durante o doutorado, com a alegria de conviver com meus sobrinhos Luca, que nasceu no dia que descobri que ingressaria no doutorado, e Yuri. A Deborah, François e Nathália pelo apoio incondicional. À Nathália Lisboa e à Tatiana Amormino, muito obrigada pela ajuda 
constante e por estarem sempre presentes. E a todos os meus amigos e familiares que, mesmo à distância, sempre me incentivaram.

Por fim, agradeço ao Lucas pelo incentivo, amparo, paciência, apoio, estímulo, torcida e amor. Foi uma aventura viver esse desafio ao seu lado. Que venham as novas aventuras de nossas vidas. 



\section{RESUMO}

DELIGNE, Maysa de Sá Pittondo. Efeitos das decisões no processo administrativo tributário. 2020. 216f. Doutorado - Faculdade de Direito, Universidade de São Paulo, São Paulo, 2020.

O principal objetivo deste trabalho é identificar a espécie de decisão administrativa tributária passível de ser dotada de estabilidade plena, com eficácia material e futura para as partes envolvidas na lide administrativa (sujeito passivo e Fazenda). Nesse sentido, enfrenta-se o problema da extensão material ou objetiva das decisões administrativas tributárias, para além das balizas do processo em que foram formadas, demarcando quais decisões e quais questões decididas pela autoridade julgadora administrativa são passíveis de serem dotadas de "força de lei" para as partes do processo administrativo tributário. Para alcançar esse propósito, a pesquisa perpassa primeiramente pela desconstrução das premissas trazidas pela doutrina pátria para admitir a atividade de revisão dos atos administrativos tributários como mero exercício de autotutela pela Administração Pública Tributária, de forma a reconhecer o exercício de verdadeira função jurisdicional nesta seara no julgamento de litígios tributários. São identificadas as competências relacionadas ao processo administrativo tributário, tanto para legislar sobre esta matéria, como quanto aos órgãos administrativos competentes para desempenhar a função jurisdicional. Em seguida, são identificados os elementos e o conteúdo da decisão administrativa tributária, diferenciando-a do regime jurídico dos atos administrativos tributários, com a verificação do pedido e da causa de pedir no processo administrativo tributário, juntamente com as questões passíveis de serem invocadas pelas partes, entre as quais estão as questões preliminares e as questões de mérito (principais e prejudiciais), de forma a delimitar o objeto do processo administrativo tributário. Admitida a natureza jurídica jurisdicional das decisões administrativas tributárias, com efetiva participação das partes à luz do contraditório, ampla defesa e devido processo legal, o regime jurídico para sua modificação é distinto dos atos administrativos tributários, produzindo efeitos como atos jurisdicionais e não administrativos. Partindo do gênero de estabilidades processuais, do qual a coisa julgada é apenas uma de suas espécies, identificam-se diferentes tipos de efeitos preclusivos no processo administrativo tributário, inclusive para as decisões administrativas tributárias, dotadas de características e efeitos próprios estabelecidos em lei. Identificada que somente a decisão administrativa tributária definitiva favorável ao sujeito passivo é dotada de estabilidade plena, com eficácia material e futura para as partes do processo administrativo tributário, investiga-se o que pode se admitir como estável (conteúdo da estabilidade), quais os efeitos sobre condutas passadas, até quando a estabilidade perdura e de que forma é possível alterar o que foi decidido com estabilidade plena. Reconhece-se que o conteúdo das decisões administrativas tributárias que será estabilizado deve se referir àquelas questões admitidas como essenciais para formar a convicção do julgador (ratio decidendi), identificando aqueles elementos de fato e de direito passíveis de orientar a conduta das partes na relação jurídica tributária.

Palavras-chave: Direito tributário. Processo administrativo tributário. Jurisdição. Eficácia. Estabilidade das decisões administrativas tributárias. 



\begin{abstract}
DELIGNE, Maysa de Sá Pittondo. Decision's effects on tax administrative procedures. 2020. 216f. Doctorate - Law School, University of São Paulo, São Paulo, 2020.

The main objective of this paper is to identify the sort of tax administrative decision that can have full stability, producing material and future effects for the parties involved in the administrative dispute (taxpayer and Treasury). In this sense, the problem of the material or objective extension of the tax administrative decisions is dealt with, beyond the ambit of the process in which they were formed, setting out which decisions and which issues decided by the administrative judge are likely to be endowed with the "force of law" for the parties in the tax administrative procedures. To achieve this purpose, the research first deconstructs the premises brought by the Brazilian doctrine in order to consider the review of the administrative tax acts by the Public Tax Administration as mere internal review procedure, in order to recognize the exercise of true judicial function by that authority when resolving tax disputes. The competences related to the tax administrative procedure are identified, to legislate on this matter and to judge as administrative organs with judicial function. Afterward, the elements and content of the tax administrative decision are identified, differentiating this decision from the legal framework of the tax administrative acts, indicating the subject-matter and the cause of action in the tax administrative procedures, herewith the issues that may be presented by the parties, including preliminary questions and issues of merit (main and preliminary questions), in order to delineate the object of the tax administrative procedure. Considering the judicial nature of tax administrative decisions, with effective participation of the parties based on adversarial principle, principle of broad defense and due process of law, the legal framework for its modification is diverse from administrative tax acts, producing effects as judicial acts, and not administrative ones. Stem from the genre of procedural stability, of which the res judicata is only one of its kind, different types of preclusive effects in the tax administrative process are identified, including for tax administrative decisions, having their own characteristics and effects established by law. As the definitive tax administrative decision favorable to the taxpayer is the only one endowed with full stability, with material and future effectiveness for the parties to the tax administrative procedure, the investigations regards the matters that can be admitted as stable (content of stability), which effects can be produced to past conducts, until when the stability endures and how is the proceeding to change what has been decided with full stability. It is recognized that the content of tax administrative decisions that will be stabilized should refer to those issues admitted as essential to forming the judge's reasons to decide (ratio decidendi), identifying the legal and factual elements that may guide the conduct of the parties in the tax legal relationship.
\end{abstract}

Keywords: Tax Law. Tax administrative procedure. Jurisdiction. Efficiency. Stability of tax administrative decisions. 



\section{RÉSUMÉ}

DELIGNE, Maysa de Sa Pittondo. Les effets des décisions sur les procédures administratives fiscales. 2020. 216f. Doctorat - Faculté de Droit, Université de São Paulo, São Paulo, 2020.

L'objectif principal de ce travail est d'identifier le type de décision administrative fiscale dont la stabilité est totale et avec une efficacité matérielle et future pour les parties impliquées dans le litige administratif (contribuable et Ministère des Finances). Dans ce sens, le problème de l'extension matérielle ou objective des décisions administratives fiscales est traité au-delà des repères du procès au sein duquel elles ont été formulées. Il est ainsi possible d'identifier quelles décisions et questions sont tranchées par l'autorité administrative de jugement et susceptibles d'avoir «force de loi» pour les parties de la procédure administrative fiscale. Dans ce but, la recherche passe d'abord par la déconstruction des prémisses de la doctrine de la patrie pour considérer l'activité de révision des actes administratifs fiscaux comme simple exercice d'autoprotection de l'administration fiscale publique afin de reconnaître l'exercice d'une véritable fonction juridictionnelle dans ce domaine au Brésil dans le cadre des jugements de litiges fiscaux. Les compétences liées au processus administratif fiscal sont identifiées pour légiférer en la matière et pour que les organes administratifs soient compétents pour exercer la fonction judiciaire. Ensuite, les éléments et le contenu de la décision administrative fiscale sont identifiés pour les différencier du régime juridique des actes administratifs fiscaux en vérifiant la demande et la cause de la demande du procès administratif fiscal ainsi que les questions qui peuvent être soulevées par les parties. Parmi ces questions se trouvent les questions préliminaires et de fond (questions principales et préliminaires) pour délimiter l'objet de la procédure administrative fiscale. Une fois admise la nature juridique des décisions administratives fiscales, avec une participation effective des parties à la lumière de la défense large et contradictoire et de l'application régulière de la loi, le régime juridique de sa modification se distingue des actes fiscaux administratifs et comportent des conséquences en tant qu'actes judiciaires non administratifs. Sur la base du type de stabilité procédurale -la chose jugée n'en représente qu'un seul-, nous identifions différents types d'effets exclusifs dans le processus administratif fiscal, y compris pour les décisions administratives fiscales ayant leurs propres caractéristiques et effets établis par la loi. Une fois identifié que seule la décision administrative fiscale définitive favorable au contribuable est dotée d'une stabilité totale, d'une efficacité matérielle et future pour les parties à la procédure administrative fiscale, nous enquêtons sur ce qui peut être considéré comme stable (contenu de stabilité) et quels en sont les effets sur les comportements passés. Ce même lorsque la stabilité perdure et comment il est possible de modifier ce qui a été décidé en toute stabilité. Il est reconnu que le contenu des décisions administratives qui sera stabilisé doit être en lien avec les questions admises comme essentielles pour former le jugement du juge (ratio decidendi) en identifiant les éléments de fait et de droit qui peuvent orienter la conduite des parties dans la relation juridique fiscale.

Mots-clés: Droit fiscal. Procédure administrative fiscale. Juridiction. Efficacité. Stabilité des décisions administratives fiscales. 



\section{LISTA DE FIGURAS E QUADROS}

Figura 1 - Espécies de decisões administrativas tributárias 165

Quadro 1 - Síntese das questões preliminares e de mérito passíveis de PAT quando formuladas em defesas administrativas do sujeito passivo. 125

Quadro 2 - Hipóteses de preclusão processual à luz da doutrina clássica 157 



\section{LISTA DE SIGLAS E ABREVIATURAS}

\begin{tabular}{|c|c|}
\hline APA & - Administrative Procedure Act \\
\hline CARF & - Conselho Administrativo de Recursos Fiscais \\
\hline $\mathrm{CF} / 1988$ & - Constituição da República Federativa do Brasil de 1988 \\
\hline COFINS & - Contribuição para o Financiamento da Seguridade Social \\
\hline COSIT & - Coordenação-Geral de Tributação \\
\hline CPC/1973 & - Código de Processo Civil de 1973 \\
\hline CPC/2015 & - Código de Processo Civil de 2015 \\
\hline CSLL & - Contribuição Social sobre o Lucro Líquido \\
\hline CSRF & - Câmara Superior de Recursos Fiscais do CARF \\
\hline CTN & - Código Tributário Nacional \\
\hline IPI & - Imposto sobre Produtos Industrializados \\
\hline IR & - Imposto sobre a Renda \\
\hline IRPF & - Imposto sobre a Renda da Pessoa Física \\
\hline IRS & - Internal Revenue Service \\
\hline LEF & - Lei de Execução Fiscal \\
\hline LINDB & - Lei de Introdução às Normas do Direito Brasileiro \\
\hline NJP & - Negócio jurídico processual \\
\hline NT & - Não tributado \\
\hline PAT & - Processo Administrativo Tributário \\
\hline PGFN & - Procuradoria-Geral da Fazenda Nacional \\
\hline PIS & - Programa de Integração Social \\
\hline $\mathrm{RE}$ & - Recurso Extraordinário \\
\hline REsp & - Recurso Especial \\
\hline RICARF & - Regimento Interno do Conselho Administrativo de Recursos Fiscais \\
\hline SRF & - Secretaria da Receita Federal do Brasil \\
\hline STF & - Supremo Tribunal Federal \\
\hline STJ & - Superior Tribunal de Justiça \\
\hline TIPI & - Tabela de Incidência do IPI \\
\hline TIT & - Tribunal de Impostos e Taxas \\
\hline
\end{tabular}





\section{SUMÁRIO}

INTRODUÇÃO

\section{COMPETÊNCIA E FUNÇÃO DOS JULGADORES NO PROCESSO} ADMINISTRATIVO TRIBUTÁRIO

1.1 A atividade de revisão dos julgadores administrativos tributários .29

1.1.1 Desconstruindo as premissas da autotutela: crítica ao monopólio da jurisdição no Brasil.

1.1.1.1 Jurisdição e a imparcialidade: a necessária distinção entre "poder" $e$ função jurisdicional.

1.1.1.2 Perspectiva histórica e de direito comparado: a evolução normativa do contencioso administrativo tributário no Brasil.

1.1.2 As garantias processuais do contraditório, da ampla defesa e do devido processo legal: o contencioso administrativo tributário e a precisa utilização do signo processo administrativo

1.1.3 Natureza jurisdicional da atividade de revisão: a função do julgador de resolver o litígio administrativo.

1.2 Competência no processo administrativo tributário: legislativa e jurisdicional

1.3 Conclusão parcial: competência e função dos julgadores no processo administrativo tributário.

\section{CONTEÚDO E ESTRUTURA DA DECISÃO ADMINISTRATIVA}

TRIBUTÁRIA 85

2.1 Natureza jurídica da decisão administrativa tributária 85

2.2 Os elementos essenciais das decisões administrativas tributárias 93

2.2.1 Relatório, fundamentos e conclusão 93

2.2.2 Motivo, motivação e fundamento: conceitos, diferenças e aproximações. 95

2.3 Delimitação do objeto do processo administrativo tributário: as tutelas jurisdicionais.

2.3.1 As questões de fato e de direito no processo administrativo tributário: questões preliminares, questões prejudiciais, questões principais e questões de ordem pública.

2.3.2 Limites para a revisão do ato administrativo tributário: distinção entre a tutela jurisdicional administrativa e a autotutela da Administração. 
2.3.3 Ônus da prova e atribuições instrutórias do julgador administrativo: princípio da verdade material.

2.4 Conclusão parcial: conteúdo e estrutura da decisão proferida no processo administrativo tributário

3.1 Estabilidades processuais no processo administrativo tributário .135

3.1.1 Efeitos das decisões administrativas na doutrina e na jurisprudência: críticas à abordagem da preclusão administrativa e da coisa julgada administrativa.

3.1.2 Hipóteses de estabilidade processual no processo administrativo tributário reconhecidas pela doutrina clássica.

3.2 Espécies de decisão administrativa tributária e seu grau de estabilidade extraprocessual

3.2.1 Decisões administrativas tributárias definitivas contrárias aos sujeitos passivos de conteúdo material (favoráveis ao fisco): estabilidade extraprocessual relativa 166

3.2.2 Decisões administrativas tributárias definitivas favoráveis aos sujeitos passivos de conteúdo material: estabilidade extraprocessual plena . 168

3.3 Efeitos extraprocessuais das decisões administrativas tributárias definitivas favoráveis aos sujeitos passivos de conteúdo material .170

3.3.1 Efeitos em outros processos administrativos em curso referentes às mesmas partes

3.3.2 Efeitos nas relações jurídicas tributárias ......................................................175

3.3.3 Conteúdos estabilizados das decisões administrativas tributárias 177

3.3.4 Como operar mudanças na estabilidade das decisões administrativas tributárias

CONCLUSÕES

REFERÊNCIAS

Livros, artigos e demais publicações .195

Normas e julgados 


\section{INTRODUÇÃO}

Todo modelo é uma ferramenta de trabalho que ganha corpo com a prática doutrinária e, especialmente, jurisprudencial. Esperar mais do que isso é ingenuidade. ${ }^{1}$

Em uma época em que se buscam meios alternativos de resolução de conflitos junto à Administração Pública, um modo clássico de solução já se encontra devidamente estruturado e formatado no ordenamento jurídico pátrio em relação aos litígios tributários, embora não seja devidamente valorizado pela doutrina: o processo administrativo tributário. ${ }^{2}$ Neste trabalho, pretende-se enaltecer a atividade jurisdicional administrativa tributária, identificando os efeitos de que as decisões tomadas pelos julgadores administrativos tributários se revestem.

A hipótese delimitada, singular, falseável, controversa e original desta pesquisa pode ser sintetizada da seguinte forma: a decisão administrativa tributária definitiva favorável ao sujeito passivo é a espécie de decisão dotada de estabilidade extraprocessual quanto às questões nela decididas, com eficácia material e futura para as partes envolvidas na lide administrativa (sujeito passivo e Fazenda). Busca-se enfrentar, portanto, o problema quanto à extensão material ou objetiva da decisão administrativa tributária, para além das balizas do processo em que foi formada, demarcando quais as decisões e quais as questões decididas pela autoridade julgadora administrativa que são dotadas de "força de lei" para as partes do processo administrativo tributário.

A hipótese é delimitada por se referir especificamente aos efeitos da decisão administrativa tributária definitiva favorável ao sujeito passivo a que se refere o art. 45 do Decreto $\mathrm{n}^{\mathrm{o}}$ 70.235/1972. Trata-se de uma espécie de decisão definitiva com efeitos distintos da decisão administrativa tributária contrária ao sujeito passivo do art. 43 do mesmo decreto.

A hipótese é não trivial, porquanto a estabilidade extraprocessual das decisões administrativas tributárias, leia-se, para além do processo no qual foram proferidas, não é admitida de forma clara pelos expoentes da doutrina brasileira. Majoritariamente, restringem-se os efeitos da decisão administrativa favorável ao sujeito passivo em uma perspectiva intraprocessual, tão somente para extinguir o crédito tributário objeto da

\footnotetext{
${ }^{1}$ SILVA, Virgílio Afonso da. A constitucionalização do direito: os direitos fundamentais nas relações entre particulares. São Paulo: Malheiros, 2005. p. 176.

2 Quanto à busca de meios alternativos de resolução de conflitos, ver: MEDAUAR, Odete. Meios consensuais de solução de litígios relativos à administração pública. In: SCHIRATO, Vitor Rhein (coord.). Estudos atuais sobre ato e processo administrativo. Rio de Janeiro: Lumen Juris, 2017. p. 5.
} 
decisão, com fulcro no art. 156, IX, da Lei n ${ }^{\circ}$ 5.172/1966, Código Tributário Nacional $(\mathrm{CTN}) .{ }^{3} \mathrm{O}$ regime jurídico das decisões administrativas tributárias é equiparado ao dos atos administrativos tributários, afastando qualquer exercício de função jurisdicional pela Administração Pública Tributária. Com respaldo nas concepções da jurisdição una brasileira, monopolizada pelo Poder Judiciário, e da parcialidade do julgador administrativo, entende-se que o processo administrativo tributário seria tão somente exercício de função de autotutela da Administração sobre seus atos. ${ }^{4}$ Mesmo aqueles autores que buscam reconhecer a existência de uma "coisa julgada administrativa" ou aproximar as decisões administrativas tributárias à figura da coisa julgada judicial se limitam a atribuir-lhes efeitos meramente intraprocessuais. ${ }^{5}$

Por sua vez, autores que admitem a existência de um contencioso administrativo tributário equiparam as decisões administrativas aos atos administrativos, atraindo todo o regime jurídico desses atos para sua edição e modificação, com a aproximação de noções de processo por exigência constitucional do art. 5, LV, da Constituição Federal de 1988 $(\mathrm{CF} / 1988){ }^{6}$ Por conseguinte, deixa-se de diferenciar os efeitos e formas de modificação da decisão administrativa tributária proferida no bojo do processo administrativo tributário

\footnotetext{
${ }^{3}$ XAVIER, Alberto. Do lançamento: teoria geral do ato, do procedimento e do processo tributário. Rio de Janeiro: Forense, 1997. p. 268; ROCHA, Sérgio André. Processo administrativo fiscal: controle administrativo do lançamento tributário. São Paulo: Almedina, 2018. p. 263; SANTI, Eurico Marcos Diniz de; ZUGMAN, Daniel Leib. Decisões administrativas definitivas não podem ser rediscutidas no poder judiciário. In: X Congresso Nacional de Estudos Tributários: Sistema tributário brasileiro e as relações internacionais. São Paulo: Noeses, 2013. p. 313-314; CARVALHO, Paulo de Barros. As decisões do Carf e a extinção do crédito tributário. Revista Dialética de Direito Tributário, São Paulo, n. 212, p. 97-98, maio 2013 e Curso de Direito Tributário. 29. ed. São Paulo: Saraiva, 2018. p. 472; SCHOUERI, Luís Eduardo. Direito Tributário. 8. ed. São Paulo: Saraiva, 2018. p. 697.

${ }^{4}$ GUIMARÃES, Carlos da Rocha. O Processo Fiscal. In: GUIMARÃES, Carlos da Rocha. Problemas de Direito Tributário. Rio de Janeiro: Edições Financeiras, 1962. p. 113; CANTO, Gilberto Ulhôa. $O$ processo tributário: anteprojeto de lei orgânica, elaborado por Gilberto Ulhôa Canto. Rio de Janeiro: FGV, 1964. p. 66-71; COSTA, Alcides Jorge. Algumas considerações a propósito do anteprojeto de lei sobre contencioso administrativo fiscal. Com comentários de Maria Teresa Martínez de Oliveira. In: OLIVEIRA, Ricardo Mariz de; COSTA, Sérgio de Freitas (coord.). Diálogos Póstumos com Alcides Jorge Costa. São Paulo: IBDT, 2017. p. 381; FALCÃO, Amílcar de Araújo. Introdução ao Direito Administrativo. São Paulo: Resenha Tributária, 1977. p. 69; THEODORO JÚNIOR, Humberto. Curso de direito processual civil. 60. ed. Rio de Janeiro: Forense, 2019. p. 1141; DI PIETRO, Maria Sylvia Zanella. Direito Administrativo. 20. ed. São Paulo: Atlas, 2007. p. 682; JUSTEN FILHO, Marçal. Curso de Direito Administrativo. 10. ed. São Paulo: Revista dos Tribunais, 2014. p. 379; MACHADO SEGUNDO, Hugo de Brito. Processo Tributário. Série Leitura Jurídicas, Vol. 37. São Paulo: Atlas, 2010. p. 36.

${ }^{5}$ Pela coisa julgada administrativa, ver: MELLO, Celso Antônio Bandeira de. Curso de Direito Administrativo. 34. ed. São Paulo: Malheiros, 2019. p. 471-473. Equiparando os efeitos a coisa julgada judicial formal: XAVIER, Alberto. Do lançamento: teoria geral do ato, do procedimento e do processo tributário. Rio de Janeiro: Forense, 1997. p. 268; BOTTALLO, Eduardo Domingos. Curso de processo administrativo tributário. 2. ed. São Paulo: Malheiros, 2009. p. 188. JUSTEN FILHO, Marçal. Curso de Direito Administrativo. 10. ed. São Paulo: Revista dos Tribunais, 2014. p. 378-379.

${ }^{6}$ MINATEL, José Antonio. Procedimento e processo administrativo tributário: dupla função administrativa, com diferentes regimes jurídicos. In: ROCHA, Sérgio André (coord.). Processo Administrativo Tributário: estudos em homenagem ao Professor Aurélio Pitanga Seixas Filho. São Paulo: Quartier Latin, 2007. p. 344.
} 
daquelas decisões tomadas em procedimentos administrativos, de forma unilateral pela Administração Pública e sem exigência de contraditório e ampla defesa, como as soluções de consulta. ${ }^{7}$

Estes aspectos singulares da hipótese evidenciam, ainda, sua falseabilidade e controvérsia. A hipótese é falseável porque, não sendo possível confirmar a existência de um contencioso administrativo efetivo no Brasil, somente o Poder Judiciário seria competente para resolver litígios de forma definitiva. Nesse raciocínio, cabem ser reconhecidos às decisões administrativas tributárias tão somente efeitos intraprocessuais, não suscetíveis a atingir a relação jurídica tributária objeto do processo ou outros processos das mesmas partes. Com isso, a Administração Pública Tributária pode modificar, à luz do poder de revisão dos atos administrativos, a interpretação veiculada nas decisões definitivas favoráveis ao sujeito passivo proferidas no processo administrativo tributário. Cada processo administrativo tributário é considerado como autônomo, revisando-se individualmente os atos administrativos tributários neles lavrados (auto de infração ou despacho decisório), delimitados pelo tributo envolvido e período de apuração.

Por conseguinte, igualmente se confirma a controvérsia da hipótese, uma vez que este é o entendimento que atualmente orienta a doutrina e a jurisprudência pátrias, sem identificar e problematizar os efeitos específicos produzidos pela decisão administrativa tributária definitiva favorável ao sujeito passivo.

A originalidade, por fim, reside em reconhecer estabilidade extraprocessual à decisão administrativa tributária favorável ao sujeito passivo e às questões nela enfrentadas, como ato jurisdicional dotado de estabilidade plena por não ser passível de revisão pelo Poder Judiciário. Além disso, consideram-se as particularidades dos efeitos dessa decisão, passíveis de serem produzidos inclusive para o futuro, identificando as distinções e aproximações com a noção da coisa julgada material formada na seara judicial.

Propõe-se, portanto, que as questões decididas pela decisão administrativa definitiva favorável ao sujeito passivo produzam efeitos não apenas no processo em que foi proferida (efeito intraprocessual, reconhecido pela doutrina), mas na própria relação jurídica tributária, orientando as condutas das partes, inclusive futuras (efeitos extraprocessuais, materiais e futuros).

\footnotetext{
${ }^{7}$ BORGES, José Souto Maior. Sobre a preclusão da faculdade de rever resposta pró-contribuinte em consulta fiscal e descabimento de recurso pela Administração Fiscal. Revista Dialética de Direito Tributário, São Paulo, n. 154, p. 83, jul. 2008.
} 
Neste ponto, cumpre mencionar que distintos expoentes da doutrina pátria reconhecem a produção de efeitos futuros das decisões administrativas tributárias quando atingem a relação jurídica tributária. ${ }^{8}$ Contudo esse seria um efeito passível de ser produzido por todos os atos administrativos decisórios individuais proferidos na seara administrativa, inclusive pelas decisões proferidas de forma unilateral, sem exigência de contraditório e ampla defesa, como nos procedimentos de consulta. Não se reconhecem, portanto, efeitos distintos às decisões administrativas tributárias proferidas no exercício de função jurisdicional. Por conseguinte, a doutrina admite a alteração das razões adotadas nas decisões administrativas tributárias com base, tão somente, na função de autotutela ou revisão dos atos administrativos, inclusive à luz dos critérios de oportunidade e conveniência.

Entretanto o regime jurídico de edição e modificação das decisões administrativas tributárias é distinto dos atos administrativos tributários por consistirem em atos jurídicos proferidos no exercício de função jurisdicional do Estado. Diferencia-se, também, dos atos administrativos decisórios proferidos de forma unilateral pela Administração Pública Tributária em procedimentos de revisão de ofício (autotutela) ou de consulta, em resposta ao direito de petição em sentido estrito, sem as garantias do contraditório e da ampla defesa.

Busca-se, portanto, enfrentar na pesquisa os questionamentos em torno do problema da extensão material ou objetiva da decisão administrativa tributária definitiva favorável ao sujeito passivo, identificados a seguir, de forma sintética:

(i) Reflexos da decisão administrativa tributária definitiva favorável ao sujeito passivo na relação jurídica processual: (i.1) Quais seus efeitos sobre os processos administrativos tributários em curso do mesmo sujeito passivo? Como e em quais hipóteses essa decisão deve ser aplicada nos processos em curso e como a legislação federal disciplina sua aplicação? (i.2) São distintos os efeitos a depender

\footnotetext{
${ }^{8}$ TORRES, Ricardo Lobo. Curso de direito financeiro e tributário. 8. ed. Rio de Janeiro, Renovar, 2001. p. 249; BALEEIRO, Aliomar. Direito tributário brasileiro. Atualizada por Misabel de Abreu Machado Derzi. 12. ed. Rio de Janeiro: Forense, 2013. p. 1216; AMARO, Luciano. Direito tributário brasileiro. 15. ed. São Paulo: Saraiva, 2009. p. 341; TROIANELLI, Gabriel Lacerda. Interpretação da lei tributária: lei interpretativa, observância de normas complementares e mudança de critério jurídico. Revista Dialética de Direito Tributário, São Paulo, n. 176, p. 81, maio 2010; SOUSA, Rubens Gomes de. Compêndio de Legislação Tributária. São Paulo: Resenha Tributária, 1975. p. 193-194; ÁVILA, Humberto. Teoria da segurança jurídica. 4. ed. São Paulo: Malheiros, 2016. p. 472-478; SCHOUERI, Luís Eduardo. Direito Tributário. 8. ed. São Paulo: Saraiva, 2018. p. 697; FLÁVIO NETO, Luís. Segurança jurídica, proteção da confiança, boa-fé e proibição de comportamentos contraditórios no Direito Tributário: nemo potest venire contra factum proprium. In: ZILVETI, Fernando Aurélio. Revista Direito Tributário Atual, São Paulo, n. 36, p. 232, 2016.
} 
da instância de julgamento que proferiu a decisão (primeira ordinária, segunda ordinária ou especial)?

(ii) Extensão material da decisão administrativa tributária definitiva favorável ao sujeito passivo na relação jurídica tributária material: (ii.1) Quais questões ou matérias são dotadas de estabilidade extraprocessual? (ii.2) Quais são os reflexos da decisão administrativa irreformável nas condutas passadas do sujeito passivo por ela amparado que não foram objeto de lançamento de ofício? (ii.3) Tratando-se de uma relação jurídica de trato sucessivo e continuado, até quando o sujeito passivo pode orientar suas condutas futuras com base na decisão? Em quais hipóteses e de que maneira a interpretação adotada na decisão irreformável pode ser modificada para o futuro? (ii.4) Quando será cabível e qual o procedimento a ser seguido para a modificação das decisões administrativas tributárias favoráveis ao sujeito passivo?

Para ilustrar estes questionamentos relacionados à hipótese desta pesquisa, descreve-se uma situação hipotética, enfrentada de forma corriqueira pelos sujeitos passivos que instauram litígios administrativos no Brasil.

Após anos de discussão administrativa, o sujeito (S1) obtém um provimento final proferido por uma turma ordinária da segunda instância administrativa entendendo que um auto de infração (A1) lavrado para o período de apuração (P1) deve ser cancelado. A decisão foi definitiva, pois não foi interposto recurso especial, pela Fazenda, previsto na lei administrativa. O fundamento trazido na decisão administrativa tributária definitiva favorável ao sujeito passivo para o cancelamento da autuação é que estava correta a interpretação da lei (L1) adotada por S1 para o cálculo do tributo devido no exercício de suas atividades durante o período P1. Ou seja, quando do julgamento do pedido formulado pelo sujeito passivo S1 no processo administrativo, como pressuposto lógico para o julgamento da questão principal (cancelamento, ou não, do ato administrativo tributário sob revisão), o julgador administrativo precisou enfrentar, de forma expressa na motivação da decisão, como o dispositivo da lei L1 deveria ser interpretado.

Com fulcro no art. 156, IX, do CTN, o auto de infração A1 é cancelado (como efeito tradicionalmente reconhecido pela doutrina pátria). Contudo a lei L1 disciplina uma relação jurídica tributária continuada e sucessiva, tratando de um tributo cujos fatos geradores se esgotam imediatamente em determinado momento, mas se repetem no tempo 
de maneira uniforme e continuada. ${ }^{9}$ Por essa razão, além de A1, o mesmo sujeito S1 instaurou discussão jurídica idêntica, relacionada à interpretação da L1, em outros dois processos administrativos: no auto de infração A2, lavrado para o período de apuração P2, e no auto de infração A3, lavrado para o período de apuração P3. Na análise das autuações A2 e A3, confirma-se que se trata de fundamento jurídico idêntico ao utilizado em A1. Além disso, L1 não sofreu alterações legislativas (leia-se, pelo Poder Legislativo) em P2 e P3.

As primeiras perguntas que são formuladas diante dessa situação hipotética se referem à extensão dos efeitos da decisão administrativa tributária definitiva, proferida para S1 no processo administrativo referente ao A1, para outros processos administrativos tributários em curso, nos quais S1 figure como parte. A decisão irreformável se aplica automaticamente para os autos de infração A2 e A3? Caso A2 e A3 continuem tramitando administrativamente de forma autônoma, pode a Administração resolver esses casos com base em uma interpretação da lei L1 diferente daquela alcançada em A1? O fato de a decisão não ser de autoria da última instância administrativa (instância especial) afeta os efeitos passíveis de serem produzidos pela decisão proferida em A1?

Além dos questionamentos de ordem processual, outros podem, ainda, ser formulados, avaliando os reflexos da decisão proferida em A1 na relação jurídica tributária material entre S1 e a Administração Pública Tributária: a interpretação da lei L1 é um elemento dotado de estabilidade extraprocessual, orientando as condutas das partes da relação jurídica tributária? Quais os reflexos da decisão administrativa irreformável nas condutas passadas de S1, a ela anteriores e que não foram objeto de lançamento de ofício? Até quando o sujeito $\mathbf{S 1}$ pode orientar suas condutas futuras com base na interpretação veiculada na decisão?

Com a presente pesquisa, pretende-se contribuir para o reconhecimento da relevância das decisões tomadas pelos julgadores administrativos no exercício de função jurisdicional, destacando o papel por eles desempenhado para a construção de um ordenamento dotado de segurança jurídica. ${ }^{10}$

Sem considerar os pronunciamentos definitivos proferidos em processos anteriores, as mesmas matérias jurídicas são reiteradamente revisitadas pelos julgadores

\footnotetext{
${ }^{9}$ ZAVASCKI, Teori Albino. Coisa julgada em matéria constitucional: eficácia das sentenças nas relações jurídicas de trato continuado. In: ZAVASCKI, Teori Albino. Eficácia das Sentenças na Jurisdição Constitucional. São Paulo: RT, 2001. p. 4 Disponível em: http://www.abdpc.org.br/abdpc/artigos/Teori\%20Zavascki\%20-\%20formatado.pdf. Acesso em: $1^{\circ}$ out. 2018.

${ }^{10}$ ÁVILA, Humberto. Teoria da Segurança Jurídica. 4. ed. São Paulo: Malheiros, 2016. p. 143-706.
} 
administrativos para os mesmos sujeitos passivos, o que pode resultar em conclusões opostas. A alteração da posição irreformável do órgão jurisdicional pode ocorrer pelo simples motivo, discricionário, de alteração da composição do órgão julgador. Ou mesmo porque o julgador mudou seu entendimento sobre a matéria.

Com isso, os sujeitos passivos não possuem segurança para saber qual o posicionamento da Administração Pública Tributária, recebendo, sobre a mesma questão jurídica controvertida, decisões em sentidos diametralmente opostos, em razão de terem sido proferidas na revisão de atos administrativos tributários distintos. A falta de preocupação com os pronunciamentos proferidos pela Administração Pública Tributária no exercício de função jurisdicional gera incongruências na aplicação, dificultando a identificação das normas jurídicas que orientam as condutas dos sujeitos.

Cumpre mencionar que no processo administrativo tributário federal há mecanismos previstos na organização interna do Conselho Administrativo de Recursos Fiscais (CARF) que buscam afastar julgamentos de mérito conflitantes. Contudo esses instrumentos, isolados e sem a noção da estabilidade das decisões administrativas, não são suficientes para resolver os problemas identificados, na extensão proposta neste trabalho.

Com efeito, o art. $6^{\circ}, \S 1^{\circ}$, do Regimento Interno do CARF, aprovado pela Portaria

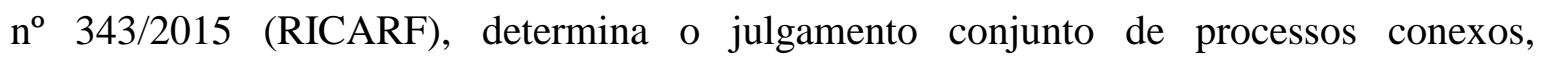
decorrentes ou reflexos. Todavia, para ser admitido como conexo ou decorrente ou reflexo, é necessário que os processos se refiram a fatos e períodos de apuração idênticos. Não resolvem, portanto, o problema aqui exposto: a possibilidade de processos administrativos, lavrados com motivação idêntica, em uma mesma relação jurídica tributária processual, serem julgados de forma distinta, exclusivamente por se referirem a outro período de apuração. Sem qualquer diferença significativa nos fatos analisados, a autonomia dos processos administrativos tributários poderá implicar a veiculação de interpretação jurídica distinta em processos que envolvam controvérsias idênticas, instaurado pelo mesmo sujeito passivo, independentemente da existência de decisão administrativa definitiva favorável ao sujeito passivo.

Por sua vez, o art. 47, $\S 1^{\circ}$, do RICARF, indica que, "quando houver multiplicidade de recursos com fundamento em idêntica questão de direito, será formado lote de recursos repetitivos", que serão julgados de forma idêntica. Trata-se de dispositivo relevante, por reconhecer a importância do julgamento uniforme das questões jurídicas pelas decisões administrativas. No entanto essa previsão não considera eventuais peculiaridades entre os 
contribuintes, inclusive a existência de uma decisão administrativa tributária definitiva anterior que possa ter sido proferida em sentido favorável a um sujeito passivo.

Além disso, esses instrumentos de julgamento não são suficientes para garantir a eficácia extraprocessual da decisão administrativa tributária, uma vez que, ainda que todos os processos idênticos em trâmite no CARF sejam agrupados para julgamento conjunto (para a aplicação das mesmas razões da decisão administrativa tributária definitiva), é possível que continuem em trâmite outros processos administrativos tributários nos órgãos de primeira instância administrativa (Delegacias de Julgamento), com a mesma lide. Com isso, é possível que a mesma matéria, já julgada de forma definitiva e com estabilidade plena, seja novamente apreciada pelas instâncias de julgamento, de forma distinta.

Nesse sentido, igualmente se contribui com a redução de litígios administrativos, por meio da estabilização substancial e não meramente formal das relações jurídicas tributárias na forma já garantida pelo ordenamento jurídico pátrio, evitando a repetição de discussões administrativas já definitivamente encerradas para o mesmo sujeito passivo. Garante-se, inclusive, a duração razoável do processo e a celeridade processual, almejadas pelo art. $5^{\circ}$, LXXVIII, da CF/1988.

Este trabalho está dividido em três capítulos, além desta introdução. No primeiro são firmados os alicerces da competência e a função dos julgadores no processo administrativo tributário. Após desconstruir as premissas de que parte a doutrina pátria para admitir a atividade de revisão dos atos administrativos tributários como mero exercício de autotutela pela Administração Pública Tributária, assevera-se o exercício de função jurisdicional no processo administrativo tributário. Em seguida, passa-se à análise das competências relacionadas ao processo administrativo tributário, tanto para legislar sobre esta matéria, como quanto aos órgãos competentes para desempenhar a função jurisdicional na seara da Administração Pública Tributária.

No segundo capítulo são identificados os elementos e o conteúdo da decisão administrativa tributária, diferenciando-os do regime jurídico dos atos administrativos tributários. Busca-se sedimentar os conceitos, diferenças e aproximações dos signos motivo, motivação e fundamentos nos atos administrativos tributários e nas decisões administrativas tributárias para, em seguida, delimitar o objeto do processo administrativo tributário. Essa última análise perpassa a análise do pedido e da causa de pedir no processo administrativo tributário, juntamente com a verificação das questões passíveis de serem invocadas pelas partes, entre as quais estão as questões preliminares e as questões de mérito (questões principais e questões prejudiciais). São analisadas ainda peculiaridades na 
atividade de julgamento administrativo, como os limites para a revisão dos atos administrativos tributários e a postura ativa do julgador administrativo no impulso e instrução do processo.

Por fim, o terceiro capítulo se dedica à análise dos efeitos das decisões administrativas tributárias, buscando enfrentar os problemas apontados acima. Nesse capítulo busca-se afastar a ideia de que a coisa julgada seria a forma de estabilidade processual por excelência, para reconhecê-la como uma das diferentes espécies de estabilidade processual, cuja forma mais geral é a preclusão, gênero conceituado de forma distinta da doutrina tradicional, como a estabilidade interna ou externa ao processo (intraprocessual ou extraprocessual), com ou sem efeitos materiais (para a relação jurídica material controvertida). Além da identificação das diferentes espécies de estabilidades processuais existentes no processo administrativo tributário, são identificadas as diferentes espécies de decisões administrativas tributárias, bem como suas diferentes formas de estabilidade. 


\section{CONCLUSÕES}

Parte das conclusões alcançadas ao longo desta pesquisa foram sintetizadas ao final dos Capítulos 1 e 2, visando identificar as premissas adotadas para o estudo da eficácia das decisões administrativas tributárias. Sem pretender reiterar todas aquelas considerações, mas identificar de forma sintética os pontos considerados essenciais, assinala-se:

a) Quando do exercício da função de julgamento, a autoridade administrativa tributária desempenha verdadeira função jurisdicional, de compor o conflito jurídico instaurado pelo sujeito por meio do processo, ao final do qual exara decisão administrativa na qual veicula a interpretação da lei admitida como correta para o caso concreto analisado;

b) A decisão administrativa tributária é um ato jurídico jurisdicional, que possui como conteúdo uma tutela jurisdicional a ser identificada a partir dos pedidos formulados no ato administrativo tributário e na defesa administrativa apresentada pelo sujeito passivo;

c) Para sua edição, a decisão administrativa tributária deve necessariamente envolver o sujeito passivo, dando a ele a possibilidade de participação à luz dos princípios do devido processo legal, do contraditório e da ampla defesa. Eles exigem que a decisão administrativa não seja um ato unilateral, mas que enfrente, em sua fundamentação, os argumentos e provas apresentados pelas duas partes ao longo do processo. Uma vez que a decisão administrativa tributária não é exarada de forma unilateral, esse ato jurisdicional exige um regime jurídico de modificação distinto dos atos administrativos em geral, que são necessariamente unilaterais;

d) O relatório, os fundamentos e a conclusão são elementos essenciais da decisão administrativa. No relatório, são sintetizados os acontecimentos do processo e os argumentos das partes, com todas as questões de fato e de direito invocadas a serem enfrentadas no fundamento da decisão. Na motivação, a decisão administrativa tributária deve considerar os argumentos relevantes para a formação da convicção (ratio decidendi), resolvendo todas as questões necessárias ao julgamento do pedido, inclusive as questões prejudiciais (art. 31, do Decreto $n^{0}$ 70.235/1972). Na conclusão, é fornecida a resposta à tutela jurisdicional pleiteada, com a solução à questão principal trazida pelo sujeito passivo, podendo ser constitutiva ou condenatória. Quaisquer dessas tutelas 
envolvem, necessariamente, uma tutela declaratória que as antecede, relacionada ao direito pleiteado ou à relação jurídica tributária controversa.

Ao se reconhecer que a Administração Pública Tributária desempenha função jurisdicional quando da revisão dos atos administrativos tributários, os atos processuais administrativos e as decisões administrativas tributárias atraem o regime jurídico aplicável ao processo e aos atos jurisdicionais. Assim, com fulcro nessas premissas, foi possível aplicar o gênero das estabilidades processuais ao processo tributário administrativo no Capítulo 3, sendo alcançadas as seguintes conclusões relevantes para confirmar a hipótese desta pesquisa trazida na introdução:

1. Partindo do gênero de estabilidades processuais, do qual a coisa julgada é apenas uma de suas espécies, identificam-se diferentes tipos de efeitos preclusivos no processo administrativo tributário, inclusive para as decisões administrativas tributárias, dotadas de características e efeitos próprios estabelecidos em lei. A própria doutrina tradicional reconhece diferentes efeitos preclusivos no curso do processo administrativo tributário, que foram sintetizados no trabalho. Contudo, não são reconhecidos de forma clara os efeitos extraprocessuais materiais para as decisões administrativas tributárias, o grau de força da estabilidade dessas decisões e a necessidade de se manter o que foi decidido;

2. O grau de estabilidade das decisões administrativas tributárias é identificado para os pronunciamentos já definitivos, assim entendidos como aqueles para os quais não cabe recurso (art. 42 do Decreto $\mathrm{n}^{\mathrm{o}}$ 70.235/1972). A própria lei do processo administrativo tributário (arts. 43 e 45 do Decreto $n^{\circ} 70.235 / 1972$ ) identifica o primeiro critério de distinção entre as decisões administrativas tributárias definitivas: o critério subjetivo, diferenciando a "decisão definitiva contrária ao sujeito passivo" (ou, simplesmente, favorável ao fisco), da "decisão definitiva favorável ao sujeito passivo", que deu provimento à pretensão apresentada pelo sujeito passivo. O art. 173, II, do CTN aponta um segundo critério relevante para distinguir o regime jurídico a ser aplicável para as decisões, qual seja, o critério material, relacionado à matéria enfrentada na decisão, distinguindo as decisões materiais ou declaratórias que enfrentam questões relacionadas aos elementos da regra matriz de incidência tributária e a relação jurídica tributária, inclusive com a interpretação da lei aplicável 
ao caso concreto, das decisões formais ou procedimentais, que se referem tão somente às questões meramente formais do ato administrativo tributário específico objeto de revisão. Somente para as decisões administrativas tributárias definitivas favoráveis aos sujeitos passivos em matéria formal há reabertura do prazo decadencial para a lavratura de novo auto de infração;

3. Em razão da possibilidade de revisão judicial das decisões administrativas tributárias definitivas materiais contrárias ao sujeito passivo, seu grau de estabilidade é relativo, inexistindo vinculação material perene para quaisquer das partes, inclusive para a Administração Pública. Pode a Administração espontaneamente rever seu posicionamento caso seja no sentido de assegurar o direito do sujeito passivo da relação jurídica tributária, de forma a afastar qualquer lesão;

4. Por não serem suscetíveis de modificação pelo Poder Judiciário, as decisões administrativas tributárias definitivas materiais favoráveis ao sujeito passivo são dotadas de eficácia preclusiva extraprocessual material plena, tanto para a relação processual (outros processos em curso com o mesmo objeto) como para a relação jurídica material controvertida. A Administração Pública Tributária apenas garante maior grau de estabilidade a seu posicionamento quando reconhece e homologa o direito do sujeito, no qual o Estado resolveu um conflito de interesses a ele apresentado, no exercício de função jurisdicional, concluindo pelo reconhecimento de direitos pleiteados pelo sujeito passivo. Em cada caso, cabe avaliar a ocorrência da definitividade "em capítulos", de maneira semelhante ao raciocínio da coisa julgada em capítulos admitida no CPC/2015.

Portanto, confirma-se a hipótese delimitada, singular, falseável, controversa e original desta pesquisa trazida na Introdução, no sentido de que a decisão administrativa tributária definitiva favorável ao sujeito passivo é espécie de decisão administrativa dotada de estabilidade extraprocessual quanto às questões nela decididas, com eficácia material e futura para as partes envolvidas na lide administrativa (sujeito passivo e Fazenda). Enfrentando o problema quanto à extensão material ou objetiva da decisão administrativa tributária, para além das balizas do processo em que foi formada, identifica-se que somente as questões objeto das decisões administrativas tributárias definitivas material favoráveis 
ao sujeito passivo poderão ser dotadas de estabilidade plena, com "força de lei" para as partes do processo.

Com isso, foram respondidos todos os questionamentos formulados na Introdução quanto aos reflexos da decisão administrativa tributária definitiva material favorável ao sujeito passivo, abaixo objetivamente sintetizados:

(i) Efeitos da decisão administrativa tributária definitiva material favorável ao sujeito passivo na relação jurídica processual:

(i.1) As razões utilizadas como fundamento para resolver o litígio serão aplicáveis, igualmente, aos outros atos administrativos tributários fundados na mesma causa de pedir (motivação do ato administrativo tributário cancelado). As mesmas razões de julgamento adotadas para a resolução de um litígio devem ser aplicadas, de ofício, para outros processos com litígios idênticos entre as mesmas partes, em cumprimento de dever legal do art. 45 do Decreto $n^{0} 70.235 / 1972$, não se tratando de mera faculdade. A aplicação de ofício da decisão será realizada pela autoridade fiscal de origem (autoridade preparadora), com fulcro na função de autotutela do art. 149, I, do CTN. Além dos julgadores administrativos não terem mais atividade jurisdicional a desempenhar, uma vez que a tutela jurisdicional já foi prestada pela decisão administrativa tributária definitiva, é o agente fiscal na unidade preparadora de origem quem terá conhecimento de quais foram os diferentes atos administrativos tributários lavrados com a mesma motivação;

(i.2) A lei não faz qualquer distinção quanto ao grau de definitividade da decisão a depender da instância em que o pronunciamento foi proferido. Assim, independentemente da instância em que tenha sido exarada (primeira ordinária, segunda ordinária ou especial), a decisão administrativa tributária definitiva favorável ao sujeito passivo terá os mesmos efeitos e o mesmo grau de estabilidade.

(ii) Efeitos da decisão administrativa tributária definitiva material favorável ao sujeito passivo na relação jurídica tributária material:

(ii.1) O conteúdo das decisões administrativas que será estabilizado deve se referir àquelas questões admitidas como essenciais para formar a convicção do julgador 
(ratio decidendi), identificando aqueles elementos de fato e de direito passíveis de orientar a conduta das partes na relação jurídica tributária. Como definido, a ratio decidendi se refere aos pontos, assim entendidos como os argumentos e elementos de fato que foram considerados essenciais para a formação da convicção do julgador, sem os quais ele não teria alcançado a conclusão no julgamento. Com isso, todas as questões, sejam elas preliminares, principais ou prejudiciais, que sejam enfrentadas expressamente nas razões de decidir da decisão, que tenham sido objeto de efetivo contencioso no processo e que se voltem à identificação dos elementos permanentes da relação jurídica material tributária orientam as condutas das partes. Por sua vez, pontos fáticos que sejam resolvidos como questões prejudiciais (na análise da validade das provas, por exemplo) podem eventualmente confirmar condutas passadas praticadas pelas partes, impedindo a lavratura de atos administrativos tributários que atinjam a mesma circunstância fática (mesmo pressuposto de fato);

(ii.2) Com estabilidade plena e como força de lei, as razões da decisão administrativa passam a integrar a própria norma geral e abstrata que foi objeto de interpretação quando da atividade de aplicação, orientando as condutas das partes, sejam aquelas realizadas no passado como as condutas futuras. Nesse sentido, a decisão administrativa tributária definitiva favorável ao sujeito passivo produz efeitos sobre a relação jurídica material. Com isso, fatos geradores passados praticados pelo sujeito passivo (parte do processo) atingidos pela motivação da decisão administrativa tributária definitiva não poderão ser objeto de ato administrativo tributário de lançamento de ofício com fulcro naquela mesma motivação. $\mathrm{O}$ art. 31 do Decreto $\mathrm{n}^{\circ}$ 70.235/1972 exige que a decisão enfrente em sua fundamentação todas as razões trazidas pelas partes no processo, por meio de um discurso argumentativo pelo qual são construídas normas jurídicas individuais relacionadas ao ato administrativo tributário revisado. Essas normas construídas e as razões relevantes para a convicção do julgador orientam as condutas das partes, passadas ou futuras;

(ii.3) Especificamente nas relações jurídicas tributárias materiais de trato continuado e sucessivo, as condutas das partes são orientadas, inclusive, para o futuro, aplicável enquanto não houver modificação no estado de fato ou de direito na forma do art. 505 do $\mathrm{CPC} / 2015$ : 
(ii.3.1) A alteração de estado de direito implica a superação da decisão administrativa tributária definitiva. Ela ocorrerá em razão de atos dotados de generalidade e abstração que sejam proferidos em sentido diverso das razões trazidas na decisão administrativa tributária. Nessa hipótese, a modificação da decisão será automática, sendo aplicável para os fatos geradores ocorridos após a publicação desses instrumentos normativos, em respeito à irretroatividade (art. 146 do CTN e pelo art. $2^{\circ}$, XIII, da Lei $n^{\circ}$ 9.784/1999). Além das alterações legislativas, podem ser considerados como atos dotados de generalidade e abstração aqueles que a lei assim os determinar, inclusive as decisões proferidas em sede de recurso repetitivo pelo STJ e STF, as hipóteses identificadas no $\S 6^{\circ}$ do art. 26-A do Decreto ${ }^{\circ} 70.235 / 1972$ e as súmulas editadas pelo CARF para as quais sejam atribuídos efeitos vinculantes para a Administração Fazendária por meio Portaria do Ministro (art. 75 do RICARF). Para a lavratura de um novo ato administrativo tributário que seja contrário à decisão administrativa tributária definitiva com estabilidade ampla, é necessário que a modificação no estado de direito seja expressamente motivada. $\mathrm{O}$ agente fiscal da Administração Pública Tributária possuirá o ônus argumentativo de demonstrar a modificação no estado de direito na motivação do novo ato;

(ii.3.2) A modificação no estado de fato implica a não aplicação da decisão administrativa tributária definitiva. Contudo, imputa-se novamente o ônus argumentativo à Administração Pública Tributária, por meio de lançamento de ofício posterior à decisão, de comprovar de que forma os elementos de fato (pressupostos de fato) foram alterados. Assim, sob pena de nulidade da motivação do ato de lançamento, exige-se a identificação das circunstâncias fáticas que foram alteradas em relação à decisão administrativa tributária definitiva com estabilidade plena, de forma expressa e justificada, para que ela seja afastada no caso concreto.

(ii.4) Inexiste na legislação pátria procedimento específico para a modificação das decisões administrativas tributárias dotadas de estabilidade plena. Como atos jurisdicionais administrativos, essas decisões não poderão atrair o regime jurídico de modificação dos atos administrativos, de forma unilateral pela Administração. Assim, para as decisões administrativas, é descabido se falar na possibilidade de 
modificação de suas razões por motivos de oportunidade e conveniência. Por outro lado, diferentemente da coisa julgada material judicial, para a qual há um procedimento específico de modificação (ação rescisória), as decisões administrativas tributárias favoráveis ao sujeito passivo com conteúdo material não possuem uma disciplina em lei para sua modificação pela Administração Pública Tributária. É consistente a proposta doutrinária de um processo administrativo revisional por almejar garantir o contraditório e a ampla defesa das partes que participaram da elaboração da decisão definitiva favorável ao sujeito passivo. A decisão administrativa tributária definitiva favorável ao sujeito passivo poderia ser revista nas hipóteses identificadas no art. 966 do CPC/2015. 



\section{REFERÊNCIAS}

\section{Livros, artigos e demais publicações}

ALCKMIN, Rodrigues. Tributo - Coisa julgada. Revista de direito administrativo, Rio de Janeiro, v. 134, p. 41-46, jan. 1978.

ALEXANDER, Larry. Constrained by precedent. Southern california law review, i. 63, p. 1-64, 1989.

ALEXY, Robert. Teoria da argumentação jurídica: a teoria do discurso racional como teoria da fundamentação jurídica. 3. ed. Rio de Janeiro: Forense, 2013.

ALLORIO, Enrico. Sulla dottrina della giurisdizione e del giudicato e altri studi. Milano: Giuffrè, 1957.

Diritto processuale tributario. Torino: Giuffrè, 1942.

ALMEIDA, Fernando Menezes de. Formação da teoria do direito administrativo no Brasil. São Paulo: Quartier Latin, 2015.

ALVIM, Thereza Celina Diniz de Arruda. Repensando a coisa julgada. Revista autônoma de processo, v. 2, p. 307-322, 2007.

. As questões prévias e os limites objetivos da coisa julgada. São Paulo: Revista dos Tribunais, 1977.

AMARO, Luciano. Direito tributário brasileiro. 15. ed. São Paulo: Saraiva, 2009.

ANDRADE, José Maria Arruda de; BRITO JR., Jorge Luiz. O processo tributário e o Código de Processo Civil/2015. In: MACHADO, Hugo de Brito (org.). O processo tributário e o Código de Processo Civil/2015. São Paulo: Malheiros, 2017. p. 21-42.

ARAÚJO, Florivaldo Dutra de. Motivação e controle do ato administrativo. 2. ed. Belo Horizonte: Del Rey, 2005.

ARAÚJO, Juliana Furtado Costa. Os efeitos da coisa julgada em matéria tributária sobre as relações jurídicas de trato sucessivo sob a ótica do CPC/15 em face de novo posicionamento fixado pelo Supremo Tribunal Federal. In: CONRADO, Paulo Cesar; ARAUJO, Juliana Furtado Costa (coord.). Processo tributário analítico. Volume IV: coisa julgada. São Paulo: Noeses. 2019. p. 11-25.

O precedente no novo Código de Procesos Civil e suas implicações tributárias. In: ARAÚJO, Juliana Costa Furtado; CONRADO, Paulo César (org.). O novo CPC e seu impacto no direito tributário. São Paulo: Fiscosoft, 2015. p. 101-126.

ATALIBA, Geraldo. Princípios constitucionais do processo e procedimento em matéria tributária. Revista de direito tributário, São Paulo, n. 46, p. 118-132, out-dez. 1988.

ATTARDI, Aldo. In tema di questioni pregiudiziale e giudicato. In: Studi in memoria di Eurico Guiccardi. Padova: CEDAM, 1975. p. 185-212. 
ÁVILA, Humberto. Teoria da prova: standards de prova e os critérios de solidez da inferência probatória. Revista de processo, v. 282, p. 113-139, 2018.

.Teoria da segurança jurídica. 4. ed. São Paulo: Malheiros, 2016.

. Função da Ciência do Direito Tributário: do formalismo epistemológico ao estruturalismo argumentativo. Direito tributário atual, v. 29, p. 181-204, jan. 2013.

. A separação dos poderes e as leis interpretativas modificativas de jurisprudência consolidada. In: DERZI, Misabel de Abreu Machado (coord.). Separação de poderes e efetividade do sistema tributário. Belo Horizonte: Del Rey, 2010. p. 51-66.

. O que é "devido processo legal"? Revista de processo, v. 163, p. 50-59, 2008.

. Moralidade, razoabilidade e eficiência na atividade administrativa. Revista brasileira de direito público, Belo Horizonte, v. 1, n. 1; p. 105-134, 2003.

. Repensando o princípio da supremacia do interesse público sobre o privado. Revista trimestral de direito público, São Paulo, v. 24, p. 159-180, 1998.

BACELLAR FILHO, Romeu Felipe. Breves reflexões sobre a jurisdição administrativa: uma perspectiva de direito comparado. Revista de direito administrativo, Rio de Janeiro, v. 211, p. 65-77, jan. 1998.

BALEEIRO, Aliomar. Direito tributário brasileiro. Atualizada por Misabel de Abreu Machado Derzi. 12. ed. Rio de Janeiro: Forense, 2013.

BARACHO, José Alfredo de Oliveira. Processo e Constituição: o devido processo legal. Revista da faculdade de direito da Universidade Federal de Minas Gerais n. 23-25, 1982, p. 59-103.

BARBI, Celso Agrícola. Unidade de jurisdição e justiça administrativa no Brasil. Revista da faculdade de direito da Universidade Federal de Minas Gerais, Belo Horizonte, n. 13, p. 27-42, 1973.

BARRETO, Paulo Ayres. Contribuições: regime jurídico, destinação e controle. 2. ed. São Paulo: Noeses, 2011.

BATISTA JÚNIOR, Onofre Alves; COSTA, João Leonardo Silva. O princípio da moralidade no direito administrativo tributário. Revista ABRADT fórum de direito tributário, Belo Horizonte, ano 1, n. 1. p. 79-102, jan./jun. 2017.

BECHO, Renato Lopes. Precedentes e direito tributário: nova perspectiva da legalidade tributária. In: CARVALHO, Paulo de Barros (org.). Racionalização do sistema tributário. São Paulo: Noeses, 2017. p. 1019-1034.

BECKER, Alfredo Augusto. Teoria geral do direito tributário. São Paulo: Saraiva, 1963.

BEDAQUE, José Roberto dos Santos. Breves notas sobre jurisdição e ação. In:

ZUFELATO, Camilo; YARSHELL, Flávio Luiz (org.). 40 anos da teoria geral do processo no Brasil: passado, presente e futuro. São Paulo: Malheiros, 2013. p. 537-555. 
Os elementos objetivos da demanda observados a luz do contraditório. In:

BEDAQUE, José Roberto dos Santos; CAZETTA JÚNIOR, José Jesus; TUCCI, José Rogério Cruz e (org.). Causa de pedir e pedido no processo civil: questões polêmicas. São Paulo: Revista dos Tribunais, 2002. p. 13-52.

BERÇAITZ, Miguel Angel. Jurisdiccion contencioso-administrativa. In: Enciclopedia juridica OMEBA. Tomo XVII. Buenos Aires, Libreros, 1963. p. 561-571.

BORGES, José Alfredo. Possibilidade de a Fazenda Pública questionar em juízo as decisões definitivas do conselho de contribuintes. Revista internacional de direito tributário, Belo Horizonte, v. 8, p. 365-371, jul./dez. 2007.

BORGES, José Souto Maior. Sobre a preclusão da faculdade de rever resposta prócontribuinte em consulta fiscal e descabimento de recurso pela Administração Fiscal. Revista dialética de direito tributário, São Paulo, n. 154, p. 76-91, jul. 2008. 1981. v. 4.

Lançamento tributário: tratado de direito tributário. Rio de Janeiro: Forense,

BOTTALLO, Eduardo Domingos. Curso de processo administrativo tributário. 2. ed. São Paulo: Malheiros, 2009.

. Processo administrativo tributário. In: BARRETO, Aires F.; BOTTALLO, Eduardo Domingos (coord.). Curso de iniciação em direito tributário. São Paulo: Dialética, 2004. p. 239-248.

BUENO, Cassio Scarpinella. Coisa julgada em matéria tributária: reflexões sobre a súmula 239 do STF. Revista tributária das américas, São Paulo, RT, v. 5, n. 9, p. 75-102, jan./jun. 2014.

BULYGIN, Eugenio. Essays in legal philosophy. Oxford: Oxford University Press, 2015.

CABRAL, Antonio do Passo. Coisa julgada e preclusões dinâmicas: entre continuidade, mudança e transição de posições processuais estáveis. 3. ed. Salvador: JusPodivm, 2019.

A coisa julgada formal faz sentido no sistema do CPC/2015? In: DIDIER

JÚNIOR, Fredie; CABRAL, Antonio do Passo (coord.). Coisa julgada e outras estabilidades processuais. Salvador: JusPodivm, 2018. p. 141-164.

As estabilidades processuais como categoria incorporada ao sistema do CPC. In: DIDIER JÚNIOR, Fredie; CABRAL, Antonio do Passo (coord.). Coisa julgada e outras estabilidades processuais. Salvador: JusPodivm, 2018. p. 25-60.

CAIS, Cleide Previtalli. O processo tributário. 2. ed. São Paulo: Revista dos Tribunais, 1996.

CANTO, Gilberto Ulhôa. O processo tributário: anteprojeto de lei orgânica, elaborado por Gilberto Ulhôa Canto. Rio de Janeiro: FGV, 1964.

CARDOSO, Alessandro Mendes; MELO, Anthéia Aquino. Princípio da verdade material e a produção de provas no processo administrativo tributário: atual entendimento do Conselho Administrativo de Recursos Fiscais - CARF. In: CARDOSO, Alessandro 
Mendes et al. (org.). Processo administrativo tributário. Belo Horizonte: D’Plácido, 2018. p. 545-572.

CARNELUTTI, Francesco. Diritto e processo. Napoli: Morano, 1958.

CARRAZZA, Roque Antônio. Curso de direito constitucional tributário. 26. ed. São Paulo: Malheiros, 2010.

CARVAlHO, A. A. Contreiras de. Processo administrativo tributário. 2. ed. São Paulo: Resenha Tributária, 1978.

CARVALHO, Paulo de Barros. As decisões do Carf e a extinção do crédito tributário. Revista dialética de direito tributário, São Paulo, n. 212, p. 90-102, maio 2013.

. Curso de direito tributário. 23. ed. São Paulo: Saraiva, 2011.

. Direito tributário, linguagem e método. 3. ed. São Paulo: Noeses, 2009.

CASTARDO, Hamilton Fernando. Processo tributário administrativo. 4. ed. São Paulo: IOB, 2010.

CAUBET-HILLOUTOU, Jean Noël; BUTERI, Karine. Le rôle des diferentes acteurs du procès administratif dans l'instruction contradictoire. In: GOURDOU, Jean; LECUCQ, Olivier; MADEC, Jean-Yves (direc.). Le principe du contradictoire dans le procès administratif. Paris: L'Harmattan, 2010. p. 100-113.

CAZETTA JÚNIOR, José Jesus; TUCCI, José Rogério Cruz e (org.). Causa de pedir e pedido no processo civil: questões polêmicas. São Paulo: Revista dos Tribunais, 2002.

COÊLHO, Sacha Calmon Navarro. Curso de direito tributário brasileiro. 10. ed. Rio de Janeiro: Forense, 2009.

CONRADO, Paulo Cesar. Processo tributário. São Paulo: Quartier Latin, 2004.

CONRADO, Paulo César; PRIA, Rodrigo Dalla. A aplicação do Código de Processo Civil ao Processo Administrativo Tributário. In: CONRADO, Paulo César; ARAÚJO, Juliana Furtado Costa. O novo CPC e seu impacto no direito tributário. São Paulo: Fiscosoft, 2015. p. 249-255.

CORDOPATRI, Francesco. The ratio decidendi (an historical and comparative review). In: FAZZALARI, Elio (ed.). Italian yearbook of civil procedure. Milano: Giuffré, 1991. v. I. p. 71-83.

COSTA, Alcides Jorge. Algumas considerações a propósito do anteprojeto de lei sobre contencioso administrativo fiscal. Com comentários de Maria Teresa Martínez de Oliveira. In: OLIVEIRA, Ricardo Mariz de; COSTA, Sérgio de Freitas (coord.). Diálogos póstumos com Alcides Jorge Costa. São Paulo: IBDT, 2017. p. 380-394.

. Contribuição ao estudo da obrigação tributária. São Paulo, IBDT, 2003.

CUNHA JÚNIOR, Dirley da. A separação das funções estatais ante uma nova dogmática constitucional: a necessidade de uma revisão da teoria clássica da separação de poderes. 
In: TAVARES, André Ramos et al. (org.). Estado constitucional e organização do poder. São Paulo: Saraiva, 2010. p. 265-290.

DAVID, René. Os grandes sistemas do direito contemporâneo. Trad. Hermírio A. Carvalho. São Paulo: Martins Fontes, 2002.

DE LUCCA, Rodrigo Ramina. O dever de motivação das decisões judiciais: estado de direito, segurança jurídica e teoria dos precedentes. 3. ed. Salvador: JusPodivm, 2019.

. O conceito de precedente judicial, ratio decidendi e a universalidade das razões jurídicas de uma decisão. In: NUNES, Dierle Nunes; MENDES, Aluisio; JAYME, Fernando Gonzaga (org.). A nova aplicação da jurisprudência e precedentes no CPC/2015. São Paulo: Revista dos Tribunais, 2017. p. 951-962.

DELFINO, Lúcio; NUNES, Dierle. Do dever judicial de análise de todos os argumentos (teses) suscitados no processo, a apreciação da prova e a accountability. In: LUCON, Paulo Henrique dos Santos et al. (org.). Processo civil contemporâneo: homenagem aos 80 anos do professor Humberto Theodoro Júnior. Rio de Janeiro: Forense, 2018. p. 64-83.

DELFINO, Lúcio; ROSSI, Fernando. Interpretação jurídica e ideologias: o escopo da jurisdição no Estado Democrático de Direito. Revista jurídica UNIJUS, Uberaba, v. 11, n. 15, p. 67-90, nov. 2008.

DELIGNE, Maysa de Sá Pittondo. Competência tributária residual e as contribuições destinadas à seguridade social. Belo Horizonte: D’Plácido, 2015.

DELIGNE, Maysa de Sá Pittondo; LAURENTIIS, Thais De. Alteração de critério jurídico e a jurisprudência do CARF. In: MURICI, Gustavo Lanna et al. (org.). Análise crítica da jurisprudência do CARF. Belo Horizonte: D’Plácido, 2019. p. 367-385.

DERZI, Misabel de Abreu Machado. Modificações da jurisprudência no direito tributário: proteção da confiança, boa-fé objetiva e irretroatividade como limitações constitucionais no poder judicial de tributar. São Paulo: Noeses, 2009.

DI PIETRO, Maria Sylvia Zanella. Discricionariedade administrativa na Constituição de 1988. 3. ed. São Paulo: Atlas, 2012.

Direito administrativo. 20. ed. São Paulo: Atlas, 2007.

DIDIER JÚNIOR, Fredie. Algumas novidades sobre a disciplina normativa da coisa julgada no Código de Processo Civil brasileiro de 2015. In: DIDIER JÚNIOR, Fredie; CABRAL, Antonio do Passo (coord.). Coisa julgada e outras estabilidades processuais. Salvador: JusPodivm, 2018. p. 85-104.

DINAMARCO, Cândido Rangel; LOPES, Bruno Vasconcelos Carrilho. Teoria geral do novo processo civil. 4. ed. São Paulo: Malheiros, 2019.

DÓRIA, Sampaio. O direito constitucional. São Paulo: Max Limonad, 1962.

FAERMANN, Flávia. Vinculação aos precedentes pelo ordenamento jurídico brasileiro: reflexo de um fenômeno pautado pela busca da segurança jurídica. Revista brasileira de advocacia pública - RBAP, Belo Horizonte, ano 2, n. 3, p. 223-243, jul./dez. 2016. 
FALCÃO, Amílcar de Araújo. Introdução ao direito administrativo. São Paulo: Resenha Tributária, 1977.

. Fato gerador da obrigação tributária. São Paulo: Financeiras, 1964.

FERRAZ JÚNIOR, Tércio Sampaio. Coisa julgada em matéria fiscal (identidade de objeto). Revista de direito tributário, São Paulo, Revista dos Tribunais, v. 42, n. 12, p. 73$82,1988$.

FERRAZ, Diego. A impossibilidade jurídica do questionamento judicial, pela PGFN, das decisões do Conselho de Contribuintes. Revista fórum de direito tributário, Belo Horizonte, n. 24, p. 149-162, nov./dez. 2004;

FERRAZ, Sérgio; DALLARI, Adilson Abreu. Processo administrativo. 3. ed. São Paulo: Malheiros, 2012.

FERREIRA FILHO, Manuel Gonçalves. Curso de direito constitucional. 40. ed. São Paulo: Saraiva, 2015.

FICARI, Valerio. I poteri del giudice tributario e l'oggetto del processo tributario. In: DELLA VALLE, Eugenio; FICARI, Valerio; MARINI, Giuseppe (a cura di). Il processo tributario. Milani: CEDAM, 2008. p. 161-171.

FIGUEIREDO, Lucia Valle. Curso de direito administrativo. 9. ed. São Paulo: Malheiros, 2008.

- Processo administrativo tributário e controle de constitucionalidade pelos tribunais administrativos. Revista de direito tributário, São Paulo, n. 75, p. 158-161, 1998.

FLÁVIO NETO, Luís. Segurança jurídica, proteção da confiança, boa-fé e proibição de comportamentos contraditórios no direito tributário: nemo potest venire contra factum proprium. Revista direito tributário atual, Instituto Brasileiro de Direito Tributário, São Paulo, n. 36, p. 222-239, 2016.

FOLLONI, André Parmo. Teoria do ato administrativo. Curitiba: Juruá, 2009.

FREITAS, Juarez. As políticas públicas e o direito fundamental à boa administração pública. Revista do programa de pós-graduação em direito da UFC, v. 35, p. 195-217, jan./jun. 2015.

GARCÍA VIZCAINO, Catalina. El procedimiento ante el Tribunal Fiscal de la Nación y sus instancias inferiores y superiores. 2. ed. Buenos Aires: Abeledo-Perrot, 2011.

. El Tribunal Fiscal de la Nación y la reforma tributaria de 2017. Revista de derecho tributario, número especial (Reforma Tributaria), IJ-XDI-518, 8 fev. 2018. Disponível em:

https://ar.ijeditores.com/pop.php?option=articulo\&Hash=5a3eef5103bc6a8d2d8839a03a1d f2cf. Acesso em: 16 out. 2019.

GAUDEMET, Yves. Droit administratif. 18. ed. Paris: LGDJ, 2005.

GLENDI, Cesare. L'oggetto del processo tributario. Padova: CEDAM, 1984. 
GODOI, Marciano Seabra de. Sobre a possibilidade de a Fazenda Pública reverter, em juízo, decisões definitivas dos conselhos de contribuintes. In: ROCHA, Valdir de Oliveira (coord.). Grandes questões aduais de direito tributário: $9^{\circ}$ volume. São Paulo: Dialética, 2005. p. 396-410.

GODOI, Marciano Seabra de; COSTA, Ana Cecília Battesini Pereira. Alteração de critério jurídico do lançamento: artigos 146 e 149 do Código Tributário Nacional. In: CARDOSO, Alessandro Mendes et al. (org.). Processo administrativo tributário. Belo Horizonte: D’Plácido, 2018. p. 67-87.

GRAU, Eros. O direito posto e o direito pressuposto. 6. ed. São Paulo: Malheiros, 2005.

GRINOVER, Ada Pellegrini. Ensaio sobre processualidade: fundamentos para uma nova teoria geral do processo. Brasília: Gazeta Jurídica, 2016.

GRUPENMACHER, Betina Treiger. Controle da constitucionalidade pelo Poder Executivo. In: DERZI, Misabel de Abreu Machado (coord.). Separação de poderes e efetividade do sistema tributário. Belo Horizonte: Del Rey, 2010. p. 211-234.

GUASTINI, Riccardo. Filosofia del diritto positivo. Torino: Giappichelli, 2017.

GUILLERMET, Camille-Julia. La motivation des decisions de justice: la vertu pédagogique de la justice. Paris: L’Harmattan, 2006.

GUIMARÃES, Carlos da Rocha. O processo fiscal. In: GUIMARÃES, Carlos da Rocha. Problemas de direito tributário. Rio de Janeiro: Edições Financeiras, 1962. p. 99-154.

HORVARTH, Estevão. Lançamento tributário e “autolançamento”. São Paulo: Quartier Latin, 2010.

ICHIHARA, Yoshiaki. Processo Administrativo Tributário. In: MARTINS, Ives Gandra da Silva (coord.). Processo administrativo tributário. São Paulo: Revista dos Tribunais, 2002. p. 358-359.

JACKISCH, Aline. A análise da inconstitucionalidade das normas no processo administrativo tributário. 2015. Dissertação (Mestrado em Direito) - Universidade Federal do Rio Grande do Sul, Porto Alegre, 2015.

JUSTEN FILHO, Marçal. Curso de direito administrativo. 10. ed. São Paulo: Revista dos Tribunais, 2014.

KELSEN, Hans. Teoria geral das normas. Porto Alegre: Sérgio Antônio Fabris, 1986.

LAMY, Marcelo. As funções jurisdicionais e a criação de direitos. Revista brasileira de direito constitucional-RBDC, n. 15, p. 211-244, jan./jun. 2010.

LEAL, Victor Nunes. Junta de Ajustes e Lucros - natureza de suas decisões - caráter normativo - delegação de poderes - conceito de lei. Revista de direito administrativo, Rio de Janeiro, v. 13, p. 319-326, jul. 1948.

LEÃO, Martha Toribio. O direito findamental de economizar tributos: entre legalidade, liberdade e solidariedade. São Paulo: Malheiros, 2018. 
LEITÃO, Maria Beatriz Mello. A possibilidade de revisão pelo Poder Judiciário das decisões do Conselho de Contribuintes contrárias à Fazenda Pública. In: ROCHA, Sérgio André (coord.). Processo administrativo tributário: estudos em homenagem ao Professor Aurélio Pitanga Seixas Filho. São Paulo: Quartier Latin, 2007. p. 499-520.

LIEBMAN, Enrico Tullio. Limites da coisa julgada em matéria de imposto. In:

LIEBMAN, Enrico Tullio. Estudos sobre o processo civil brasileiro. São Paulo: Saraiva, 1947. p. 171-177.

LOPES, Bruno Vasconcelos Carrilho. Limites objetivos e eficácia preclusiva da coisa julgada. 2010. 158 f. Tese (Doutorado em Direito) - Universidade de São Paulo, São Paulo, 2010.

LOPES, José Reinaldo de Lima. Filosofia analítica e hermenêutica: preliminares para uma teoria do direito como prática. Revista de informação legislativa, v. 53, p. 203-226, 2016.

LUCON, Paulo Henrique dos Santos. Garantia da motivação das decisões no Novo Código de Processo Civil brasileiro: miradas para um novo processo civil. Revista Brasileira de Direito Processual - RBDPro, Belo Horizonte, ano 23, n. 90, p. 419-436, abr./jun. 2015.

LUVIZOTTO, Juliana Cristina. Precedentes administrativos e a vinculação da atividade administrativa. Curitiba: Juruá, 2017.

MACCORMICK, Neil. Rhetoric and the rule of law: a theory of legal reasoning. Oxford: Oxford University Press, 2005.

MACCORMICK, Neil; SUMMERS, Robert (org.). Interpreting precedents: a comparative study. Aldershot: Ashgate, 1997.

MACHADO SEGUNDO, Hugo de Brito. Processo tributário. 6. ed. São Paulo: Atlas, 2012.

MACHADO, Hugo de Brito. Motivação dos atos administrativos e o interesse público. Interesse público, São Paulo, ano 1, n. 3, p. 9-25, jul./set. 1999.

Os direitos fundamentais do contribuinte e a efetividade da jurisdição. 2009. Tese (Doutorado em Direito) - Programa de Pós-Graduação em Direito, Centro de Ciências Jurídicas / FDR, Universidade Federal de Pernambuco, Recife, 2009.

MARINONI, Luiz Guilherme. Coisa julgada sobre questão. São Paulo: Thomson Reuters, 2018.

. Uma nova realidade diante do Projeto de CPC: a ratio decidendi ou os fundamentos determinantes da decisão. Interesse público - IP, Belo Horizonte, ano 15, n. 77, p. 23-85, jan./fev. 2012.

MARINS, James. Direito processual tributário brasileiro: administrativo e judicial. 10. ed. São Paulo: Revista dos Tribunais, 2017.

MARQUES NETO, Floriano Peixoto de Azevedo. A bipolaridade do direito administrativo e sua superação. In: ARAGÃO, Alexandre Santos de; MARQUES NETO, 
Floriano de Azevedo (coord.). Direito administrativo e seus novos paradigmas. 2. ed. Belo Horizonte: Fórum, 2016. p. 87-127.

MARTINS, Ricardo Marcondes. O conceito científico de processo administrativo. Revista de direito administrativo, Rio de Janeiro, v. 235, p. 321-381, jan. 2004.

MEDAUAR, Odete. O direito administrativo em evolução. 3. ed. Brasília: Gazeta Jurídica, 2017.

. Meios consensuais de solução de litígios relativos à administração pública. In: SCHIRATO, Vitor Rhein (coord.). Estudos atuais sobre ato e processo administrativo. Rio de Janeiro: Lumen Juris, 2017. p. 5-9.

Administração pública: do ato ao processo. In: ARAGÃO, Alexandre Santos de; MARQUES NETO, Floriano de Azevedo (coord.). Direito administrativo e seus novos paradigmas. 2. ed. Belo Horizonte: Fórum, 2016. p. 381-395.

Processualização e publicidade dos atos do processo administrativo fiscal. In:

ROCHA, Valdir de Oliveira (coord.). Processo administrativo fiscal. São Paulo: Dialética, 1995. p. 121-126.

MEIRELLES, Hely Lopes. Direito administrativo brasileiro. 43. ed. São Paulo:

Malheiros, 2018.

MELO, José Eduardo Soares de. Curso de Direito Tributário. 3. ed. São Paulo: Dialética, 2002.

MELLO, Celso Antônio Bandeira de. Curso de direito administrativo. 34. ed. São Paulo: Malheiros, 2019.

. A motivação dos atos da administração pública como princípio fundamental do estado de direito. Revista de direito tributário, São Paulo: Malheiros, v. 87. p. 11-21, XVI Congresso Brasileiro de Direito Tributário. s.d.

MESQUITA, José Ignácio Botelho de et al. Questões de ordem pública: revisíveis ad infinitum? In: ASSIS, Araken de et al. (coord.). Direito civil e processo: estudos em homenagem ao professor Arruda Alvim. São Paulo: Revista dos Tribunais, 2007. p. 15221532.

MESQUITA, José Ignácio Botelho de. Teses, estudos e pareceres de processo civil. São Paulo: Revista dos Tribunais, 2005. v. 1.

A coisa julgada. Rio de Janeiro: Forense, 2004.

MILESSI, Jimena C.; TEIXEIRA, Raquel Biasotto. Tribunales administrativos especializados en materia aduanera y tributaria en Argentina y en Brasil: Tribunal Fiscal de la Nación Argentina (TFN) y Consejo Administrativo de Recursos Fiscales de Brasil (CARF). Ius gentium, Curitiba, ano 7, n. 14, p. 207-229, jul./dez. 2013.

MINATEL, José Antonio. Procedimento e processo administrativo tributário: dupla função administrativa, com diferentes regimes jurídicos. In: ROCHA, Sérgio André (coord.). 
Processo administrativo tributário: estudos em homenagem ao Professor Aurélio Pitanga Seixas Filho. São Paulo: Quartier Latin, 2007. p. 321-344.

MIRANDA, Jorge. A tutela jurisdicional dos direitos fundamentais em Portugal. In: GRAU, Eros Roberto; GUERRA FILHO, Willis Santiago (org.). Direito constitucional: estudos em homenagem a Paulo Bonavides. São Paulo: Malheiros, 2001. p. 284-304.

MOREIRA, José Carlos Barbosa. Ainda e sempre a coisa julgada. Doutrinas essenciais de processo civil, v. 6, p. 679, out. 2011.

. Considerações sobre a chamada 'relativização' da coisa julgada material. In:

Temas de direito processual. Nona Série. São Paulo: Saraiva, 2007. p. 235-266.

. A eficácia preclusiva da coisa julgada material no sistema do processo civil brasileiro. In: Temas de direito processual. Primeira Série. São Paulo: Saraiva, 1977. p. 97-109.

. Questões preliminares e questões prejudiciais. In: MOREIRA, José Carlos Barbosa. Direito processual civil (ensaios e pareceres). Rio de Janeiro: Borsoi, 1971. p. 73-93.

- Questões prejudiciais e coisa julgada. 1967. Tese (Livre Docência) - Faculdade de Direito, Universidade Federal do Rio de Janeiro, Rio de Janeiro, 1967.

MOUSSALLEM, Tárek Moysés. Classificação dos tributos (uma visão analítica). In: DE SANTI, Eurico Marcos Diniz (coord.). Congresso nacional de estudos tributários. São Paulo: Noeses. 2007. v. 4. p. 601-637.

NEDER, Marcos Vinicius; LÓPEZ, Maria Teresa Martínez. Processo administrativo fiscal federal comentado. São Paulo: Dialética, 2002.

NEVES, Celso. Coisa julgada no direito tributário. Revista de direito público, ano VII, $\mathrm{n}$. 29, p. 237-244, 1974.

NERY JUNIOR, Nelson. Princípios do processo na Constituição Federal. 13. ed. São Paulo: Revista dos Tribunais, 2017.

NOGUEIRA, Rui Barbosa. A coisa julgada em direito tributário. Revista da faculdade de direito da Universidade de São Paulo, São Paulo, v. 68, n. 1, p. 91-113, $1^{\circ}$ jan. 1973.

NOHARA, Irene Patricia. O motivo no ato administrativo. São Paulo: Atlas, 2004.

OLIVEIRA, Fernanda Alvim Ribeiro de. Competência. In: THEODORO JÚNIOR, Humberto; OLIVEIRA, Fernanda Alvim Ribeiro de; REZENDE, Ester Camila Gomes Norato (coord.). Primeiras lições sobre o novo direito processual civil brasileiro (de acordo com o Novo Código de Processo Civil Lei 13.105, de 16 de março de 2015). Rio de Janeiro: Forense, 2015. p. 64-81.

OLIVEIRA, Ricardo Mariz de. Prefácio. In: NEDER, Marcos Vinicius; LÓPEZ, Maria Teresa Martínez. Processo administrativo fiscal federal comentado. São Paulo: Dialética, 2002. p. 7-12. 
PAULSEN, Leandro. Direito tributário: Constituição e Código Tributário à luz da doutrina e da jurisprudência. 14. ed. Porto Alegre: Livraria do Advogado; ESMAFE, 2012.

PECZENIK, Aleksander. On law and reason. Berlim: Springer, 2008.

PICARDI, Nicola. Jurisdição e processo. Organizador e revisor técnico da tradução: Carlos Alberto Alvaro de Oliveira. Rio de Janeiro: Forense, 2008.

PINTO, Bilac. Separação de poderes. Revista de direito administrativo, Rio de Janeiro, v. 6, p. 243-275, out. 1946.

PIZOLIO, Reinaldo. Decisão administrativa favorável ao contribuinte e a impossibilidade de ingresso da Fazenda Pública em juízo. In: PIZOLO, Reinaldo (coord.). Processo administrativo tributário. São Paulo: Quartier Latin, 2007. p. 271-282.

PORTER, David B. Where can you litigate your federal tax case? Tax notes, v. 98, p. 558560, Jan. 2003.

PORTO, Éderson Garin. A colaboração no direito tributário: por um novo perfil de relação obrigacional tributária. Porto Alegre: Livraria do Advogado, 2016.

PRIA, Rodrigo Dalla. Direito processual tributário. São Paulo: Noeses, 2020.

RAMOS, Elival da Silva. A valorização do processo administrativo. o poder regulamentar e a invalidação dos atos administrativos. In: SUNDFELD, Carlos Ari; MUÑOZ, Guillermo Andrés (org.). As leis de processo administrativo (Lei Federal 9.784/99 e Lei Paulista 10.177/98). São Paulo: Malheiros, 2000. p. 75-93.

REALE, Miguel. Revogação e anulamento do ato administrativo. 2. ed. Rio de Janeiro, Forense, 1980.

RHEINSTEIN, Max. Common law and civil law: an elementary comparison. Revista jurídica de la Universidad de Puerto Rico, p. 90-107, 1952. Disponível em http://chicagounbound.uchicago.edu/journal_articles. Acesso em 04 mai. 2018.

RIBAS, Lídia Maria Lopes Rodrigues. Processo administrativo tributário. 3. ed. São Paulo: Malheiros, 2008.

RIBEIRO, Diego Diniz. Precedentes em matéria tributária e o novo CPC. In: CONRADO, Paulo César (org.). Processo tributário analítico. São Paulo: Noeses, 2016. v. 3. p. 111140 .

RICCI, Gian Franco. Principi di diritto processuale generale. 6. ed. Torino: Giappichelli, 2015 .

ROCHA, Sérgio André. Processo administrativo fiscal: controle administrativo do lançamento tributário. São Paulo: Almedina, 2018.

RODRIGUES, Walter Piva. Coisa julgada tributária. São Paulo: Quartier Latin, 2008.

RUSSO, Pasquale. Manuale di diritto tributario: il processo tributario. 2. ed. Milano: Giuffrè, 2013. 
RUSSOMANO, Rosah. Controle jurisdicional dos atos administrativos e a Constituição vigente. Revista da faculdade de direito da Universidade Federal de Minas Gerais, n. 22, p. 115-132, 1979.

SANTI, Eurico Marcos Diniz de; ZUGMAN, Daniel Leib. Decisões administrativas definitivas não podem ser rediscutidas no poder judiciário. In: X Congresso nacional de estudos tributários: sistema tributário brasileiro e as relações internacionais. São Paulo: Noeses, 2013. p. 287-328.

SARAIVA FILHO, Oswaldo Othon Pontes. Efeitos das decisões no processo administrativo fiscal e o acesso ao poder judiciário. In: ROCHA, Sérgio André (coord.). Processo administrativo tributário: estudos em homenagem ao Professor Aurélio Pitanga Seixas Filho. São Paulo: Quartier Latin, 2007. p. 521-542.

SCAFF, Fernando Facury. Efeitos da coisa julgada em matéria tributária e livre concorrência. In: ROCHA, Valdir de Oliveira (coord.). Grandes questões atuais do direito tributário. São Paulo: Dialética, 2005. p. 110-135.

SCHAUER, Frederick. Giving Reasons. Stanford law review, v. 47, n. 4, p. 633-659, abr. 1995.

. Formalism. The yale law journal, v. 97, n. 4, p. 509-548, mar. 1988.

. Precedent. Stanford law review, v. 39, n. 3, p. 571-605, fev. 1987.

SCHIRATO, Vitor Rhein. Revisitando os poderes do administrador público. In: WALD, Aroldo et al. (org.). $O$ direito administrativo na atualidade: estudos em homenagem ao centenário de Hely Lopes Meirelles. São Paulo: Malheiros, 2017. p. 1189-1207.

SCHOUERI, Luís Eduardo. Direito Tributário. 8. ed. São Paulo: Saraiva, 2018.

- Algumas reflexões sobre a consulta em matéria fiscal. Revista Direito Tributário Atual. São Paulo: Resenha Tributária/IBDT, v. 14, p. 1-34, 1995.

SCHOUERI, Luís Eduardo; SOUZA, Gustavo Emílio Contrucci A. de. Verdade material no "processo" administrativo tributário. In: ROCHA, Valdir de Oliveira (coord.). Processo administrativo fiscal. São Paulo: Dialética, 1998. v. 3. p. 141-159.

SEIXAS FILHO, Aurélio Pitanga. Revisão da legalidade do lançamento tributário e a coisa julgada administrativa em matéria fiscal. In: ROCHA, Valdir de Oliveira (coord.). Grandes questões atuais do direito tributário. São Paulo: Dialética, 2005. p. 28-47.

2000.

. Estudos de procedimento administrativo fiscal. Rio de Janeiro: Freitas Bastos,

SENRA, Alexandre. A coisa julgada no Código de Processo Civil de 2015: premissas, conceitos, momento de formação, suportes fáticos. Salvador: JusPodivm, 2017.

SHERWIN, Emily. A defense of analogical reasoning in law. The university of Chicago law review, v. 66, n. 4, p. 1179-1197, Automn 1999.

SICA, Heitor Vitor Mendonça. Preclusão processual civil. 2. ed. São Paulo: Atlas, 2008. 
SILVA, José Afonso da. Curso de direito constitucional positivo. 26. ed. São Paulo: Malheiros, 2006.

SILVA, Virgílio Afonso da. Direitos fundamentais: conteúdo essencial, restrições e eficácia. 2. ed. São Paulo: Malheiros, 2010.

A constitucionalização do direito: os direitos fundamentais nas relações entre particulares. São Paulo: Malheiros, 2005.

SOUSA, Rosalina Freitas Martins de. A função jurisdicional adequada e a releitura do princípio da inafastabilidade do controle jurisdicional (CRFB/88, Art. 5, XXXV). 2017. Tese (Doutorado em Direito) - Universidade Federal de Pernambuco, Recife, 2017.

SOUSA, Rubens Gomes de. Compêndio de legislação tributária. São Paulo: Resenha Tributária, 1975.

Idéias gerais para uma concepção unitária e orgânica do processo fiscal. Revista de direito administrativo, Rio de Janeiro, v. 34, p. 14-33, out. 1953.

A coisa julgada no direito tributário. Revista de direito administrativo, Rio de Janeiro, v. 5, p. 48-76, jul. 1946.

. A distribuição da justiça em matéria fiscal. São Paulo: Livraria Martins, 1943.

. Coisa julgada (Dir. Fiscal). In: SANTOS, J. M. de Carvalho (org.). Repertório enciclopédico do direito brasileiro. Rio de Janeiro: Borsoi, s/d. v. IX. p. 290-301.

SOUZA, Fernanda Donnabella Camano de. Os limites objetivos e "temporais" da coisa julgada em ação declaratória no direito tributário. São Paulo: Quartier Latin, 2006.

SOUZA, Henrique Coutinho de. A ação rescisória em matéria tributária: considerações sobre o direito de lançar à luz do princípio da segurança jurídica. 2018. Dissertação (Mestrado em Direito) - Universidade de São Paulo, São Paulo, 2018.

STEINER, Eva. Judicial rulings with prospective effect-from comparison to systematisation. In: STEINER, Eva. Comparing the prospective effect of judicial rulings across jurisdictions. Cham: Springer International Publishing Switzerland, 2015. p. 2-5.

STUMPF, Silvia Roberta. Coisa julgada tributária e controle de constitucionalidade. 2012. Dissertação (Mestrado em Direito) - Universidade Federal do Rio Grande do Sul, Porto Alegre, 2012.

SUNDFELD, Carlos Ari. A importância do procedimento administrativo. Revista de direito público, São Paulo, n. 84, p. 64-74, out./dez. 1987.

TARUFFO, Michele. La fisionomia della sentenza in Italia. In: Facoltà di Giurisprudenza Università Degli Studi di Milano. Studi in onori di Enrico Allorio. Milano: Giuffrè, 1989. p. 1069-1105.

TESAURO, Francesco. Manuale del processo tributario. 2. ed. Torino: Giappichelli, 2013. 
THEODORO JÚNIOR, Humberto. Curso de direito processual civil. 60. ed. Rio de Janeiro: Forense, 2019.

. Limites objetivos da coisa julgada no novo Código de Processo Civil. In: DIDIER JÚNIOR, Fredie; CABRAL, Antonio do Passo (coord.). Coisa julgada e outras estabilidades processuais. Salvador: JusPodivm, 2018. p. 165-188.

. Coisa julgada. In: THEODORO JÚNIOR, Humberto; OLIVEIRA, Fernanda Alvim Ribeiro de; REZENDE, Ester Camila Gomes Norato (coord.). Primeiras lições sobre o novo direito processual civil brasileiro (de acordo com o Novo Código de Processo Civil Lei 13.105, de 16 de março de 2015). Rio de Janeiro: Forense, 2015. p. 343-365.

. Normas fundamentais do Processo Civil. In: THEODORO JÚNIOR, Humberto; OLIVEIRA, Fernanda Alvim Ribeiro de; REZENDE, Ester Camila Gomes Norato (coord.). Primeiras lições sobre o novo direito processual civil brasileiro (de acordo com o Novo Código de Processo Civil Lei 13.105, de 16 de março de 2015). Rio de Janeiro: Forense, 2015. p. 3-25.

. Jurisdição e competência. Revista da faculdade de direito da Universidade Federal de Minas Gerais, Belo Horizonte, n. 38, p. 145-182, 2000.

TORRES, Heleno Taveira. Coisa julgada administrativa como precedente e segurança jurídica. Conjur, 21 ago. 2019. Disponível em: https://www.conjur.com.br/2019-ago21/consultor-tributario-coisa-julgada-administrativa-precedente-seguranca-juridica. Acesso em: 21 ago. 2019.

TORRES, Ricardo Lobo. Curso de direito financeiro e tributário. 8. ed. Rio de Janeiro, Renovar, 2001.

TROIANELLI, Gabriel Lacerda. Interpretação da lei tributária: lei interpretativa, observância de normas complementares e mudança de critério jurídico. Revista dialética de direito tributário, São Paulo, n. 176, p. 76-83, maio 2010.

TSVASMAN, Rimma. No more excuses: a case for the irs's full compliance with the administrative procedure act. Brooklyn law review, v. 76, p. 840-843, 2010. Disponível em: https://brooklynworks.brooklaw.edu/blr/vol76/iss2/9. Acesso em: 25 ago. 2019.

TUCCI, José Rogério Cruz e. O regime do precedente judicial no novo CPC. In: DIDIER JÚNIOR, Fredie et al. (coord.). Precedentes. Salvador: JusPodivm, 2015. p. 445-457.

2004.

. Precedente judicial como fonte do direito. São Paulo: Revista dos Tribunais,

VALVERDE, Gustavo Sampaio. Coisa julgada em matéria tributária. São Paulo: Quartier Latin, 2004.

VELLOSO, Andrei Pitten. Modificação de critério jurídico nos lançamentos tributário. In: GOMES, Marcus Lívio; OLIVEIRA, Francisco Marconi de (coord.). Estudos tributários e aduaneiros do III seminário CARF. Brasília: Ministério da Fazenda, 2018. p. 13-38. 
VIGORITI, Vincenzo. La giustizia tributaria in Italia e in Usa. Organizzazione e struttura. Rivista di diritto tributario, 1994, I, n. 2, fev. 1994, p. 165-179.

WAMBIER, Teresa Arruda Alvim. O que é abrangido pela coisa julgada no direito processual civil brasileiro: a norma vigente e as perspectivas de mudança. Revista de processo, v. 39, n. 230, p. 75-89, abr./2014.

Anotações sobre a coisa julgada em matéria tributária. Revista da academia paranaense de letras jurídicas, Curitiba: Juruá, v. 1, p. 173-180, 2001.

WAMBIER, Teresa Arruda Alvim; MEDIDA, José Miguel Garcia. O dogma da coisa julgada, hipóteses de relativização. São Paulo: Revista dos Tribunais, 2003.

WYKROTA, Leonardo Martins. Procedimentos especiais - jurisdição voluntária. In: THEODORO JÚNIOR, Humberto et al. (org.). Primeiras lições sobre o novo direito processual civil brasileiro. Rio de Janeiro: Forense, 2015. p. 536-554.

XAVIER, Alberto. Do lançamento no direito tributário brasileiro. 3. ed. Rio de Janeiro: Forense, 2005.

Do lançamento: teoria geral do ato, do procedimento e do processo tributário. Rio de Janeiro: Forense, 1997.

YARSHELL, Flávio Luiz. Breves notas sobre a disciplina da ação rescisória no CPC 2015. In: GRINOVER, Ada Pellegrini (org.). O novo código de processo civil: questões controvertidas. São Paulo: Atlas, 2015. p. 155-169.

Tutela jurisdicional. 2. ed. São Paulo: DPJ, 2006.

ZAVASCKI, Teori Albino. Eficácia das sentenças na jurisdição constitucional. 3. ed. São Paulo: Revista dos Tribunais, 2014.

Coisa julgada em matéria constitucional: eficácia das sentenças nas relações jurídicas de trato continuado. In: ZAVASCKI, Teori Albino. Eficácia das sentenças na jurisdição constitucional. São Paulo: RT, 2001. Disponível em:

http://www.abdpc.org.br/abdpc/artigos/Teori\%20Zavascki\%20-\%20formatado.pdf. Acesso em: $1^{\text {o }}$ out. 2018.

\section{Normas e julgados}

ARGENTINA. Ley 11683, sobre procedimiento fiscal-regimen legal. Aplicación y percepción de impuestos. Capitulo XIV crea la cuenta especial de jerarquizacion. Publicada em el Boletín Oficial del 12 ene. 1933, n. 11586. Disponível em: http://servicios.infoleg.gob.ar/infolegInternet/verNorma.do?id=18771. Acesso em: 16 out. 2019.

BRASIL. [Constituição (1824)]. Constituição Politica do Império do Brasil (de 25 de março de 1824). Coleção de Leis do Império do Brasil, 1824, p. 7, v. 1. Disponível em: 
http://www.planalto.gov.br/ccivil_03/constituicao/constituicao24.htm. Acesso em: 6 dez. 2019.

- [Constituição (1891)]. Constituição da República dos Estados Unidos do Brasil (de 24 de fevereiro de 1891). Diário Oficial da União, 24 fev. 1981. Disponível em: http://www.planalto.gov.br/ccivil_03/constituicao/constituicao91.htm. Acesso em: 6 dez. 2019.

. [Constituição (1934)]. Constituição da República dos Estados Unidos do Brasil (de 16 de julho de 1934). Diário Oficial da União, 16 jul. 1934. Disponível em: http://www.planalto.gov.br/ccivil_03/constituicao/constituicao34.htm. Acesso em: 6 dez. 2019.

. [Constituição (1967)]. Emenda Constitucional n ${ }^{\text {7 }}$, de 13 de abril de 1977. Incorpora ao texto da Constituição Federal disposições relativas ao Poder Judiciário. Diário Oficial da União, 13 abr. 1977. Disponível em: http://www.planalto.gov.br/ccivil_03/constituicao/Emendas/Emc_anterior1988/emc0777.htm. Acesso em: 6 dez. 2019.

. [Constituição (1988)]. Constituição da República Federativa do Brasil de 1988. Diário Oficial da União, 5 out. 1988. Disponível em: http://www.planalto.gov.br/ccivil_03/constituicao/constituicao.htm. Acesso em: 6 dez. 2019.

Câmara dos Deputados. Projeto de Lei Complementar $n^{\circ}$ 381/2014. Estabelece normas gerais sobre o processo administrativo fiscal no âmbito das administrações tributárias da União, dos Estados, do Distrito Federal e dos Municípios. Autor: Senado Federal - Vital do Rêgo (PMDB/PB), 4 abr. 2014. Disponível em: https://www.camara.leg.br/proposicoesWeb/fichadetramitacao?idProposicao=611441. Acesso em: 17 out. 2019.

. Decreto ${ }^{\circ} 24.036$, de 26 de março de 1934. Reorganiza os serviços da administração geral da Fazenda Nacional e dá outras providências. Diário Oficial da União, 28 mar. 1934. Disponível em: http://www.planalto.gov.br/ccivil_03/decreto/19301949/D24036.htm. Acesso em: 3 dez. 2019.

. Decreto no 15.188 , de 29 de Março de 1944. Aprova o Regime da Junta de Ajuste de Lucros Extraordinários (J.A.L.E.). Coleção de Leis do Brasil de 31/12/1944 - vol. 002] (p. 619, col. 1). Disponível em: http://legis.senado.leg.br/norma/428655/publicacao/15615429. Acesso em: 6 dez. 2019.

Decreto $\mathrm{n}^{\circ} 16.581$, de 4 de Setembro de 1924. Approva o regulamento do imposto sobre a renda. Coleção de Leis do Brasil - 1924, Página 119 Vol. 3 (Publicação Original). Disponível em: https://www2.camara.leg.br/legin/fed/decret/1920-1929/decreto-16581-4setembro-1924-512544-publicacaooriginal-1-pe.html. Acesso em: 6 dez. 2019.

. Decreto $\mathrm{n}^{\mathrm{o}} 20.848$, de 23 de dezembro de 1931. Limita o número de pedidos de reconsideração nas instâncias administrativas. Diário Oficial da União - Seção 1 4/1/1932, Página 98 (Publicação Original). Disponível em: https://www2.camara.leg.br/legin/fed/decret/1930-1939/decreto-20848-23-dezembro1931-515931-norma-pe.html. Acesso em 12 jan. 2019. 
Decreto $\mathrm{n}^{\circ} 70.235$, de 6 de março de 1972. Dispõe sobre o processo administrativo fiscal, e dá outras providências. Diário Oficial da União, 7 mar. 1972. Disponível em: http://www.planalto.gov.br/ccivil_03/decreto/D70235cons.htm. Acesso em: 6 dez. 2019.

. Decreto ${ }^{\circ} 848$, de 11 de outubro de 1890. Organiza a Justiça Federal. Coleção de Leis do Brasil - 1890. Disponível em: http://www.planalto.gov.br/ccivil_03/decreto/18511899/D848.htm. Acesso em: 7 dez. 2019.

. Lei n ${ }^{\circ} 13.105$, de 16 de março de 2015. Código de Processo Civil. Diário Oficial da União, 17 mar. 2015. Disponível em: http://www.planalto.gov.br/ccivil_03/_ato20152018/2015/lei/113105.htm. Acesso em: 6 dez. 2019.

Lei $n^{\circ} 5.172$, de 25 de outubro de 1966. Dispõe sobre o Sistema Tributário Nacional e institui normas gerais de direito tributário aplicáveis à União, Estados e Municípios. Diário Oficial da União, 27 out. 1966. Disponível em: http://www.planalto.gov.br/ccivil_03/leis/15172.htm. Acesso em: 6 dez. 2019.

. Lei n ${ }^{\circ} 5.869$, de 11 de janeiro de 1973. Institui o Código de Processo Civil. Diário Oficial da União, 17 jan. 1973. Disponível em:

http://www.planalto.gov.br/ccivil_03/LEIS/L5869impressao.htm. Acesso em: 6 dez. 2019.

Lei $\mathrm{n}^{\circ} 6.830$, de 22 de setembro de 1980 . Dispõe sobre a cobrança judicial da Dívida Ativa da Fazenda Pública, e dá outras providências. Diário Oficial da União, 24 set. 1980. Disponível em: http://www.planalto.gov.br/ccivil_03/leis/16830.htm. Acesso em: 8 dez. 2019.

Lei $\mathrm{n}^{\circ} 8.212$, de 24 de julho de 1991. Dispõe sobre a organização da Seguridade Social, institui Plano de Custeio, e dá outras providências. Diário Oficial da União, 25 jul. 1991. Disponível em: http://www.planalto.gov.br/ccivil_03/leis/18212cons.htm. Acesso em: 5 dez. 2019.

. Lei n ${ }^{\circ} 9.430$, de 27 de dezembro de 1996. Dispõe sobre a legislação tributária federal, as contribuições para a seguridade social, o processo administrativo de consulta e dá outras providências. Diário Oficial da União, 30 dez. 1996. Disponível em: http://www.planalto.gov.br/ccivil_03/LEIS/L9430.htm. Acesso em: 5 dez. 2019.

. Lei $\mathrm{n}^{\circ} 9.784$, de 29 de janeiro de 1999. Regula o processo administrativo no âmbito da Administração Pública Federal. Diário Oficial da União, $1^{\circ}$ fev. 1999. Disponível em: http://www.planalto.gov.br/ccivil_03/leis/19784.htm. Acesso em: 6 dez. 2019.

. Ministério da Economia. Conselho Administrativo de Recursos Fiscais (CARF). Acórdão $n^{\circ}$ 9303-01.402, de 04/04/2011. Relator Conselheiro Gilson Macedo Rosenburg Filho. Redatora designada Conselheira Maria Teresa Martínez López.

. Ministério da Economia. Conselho Administrativo de Recursos Fiscais (CARF). Processo $n^{o}$ 10855.002338/1998-40. Publicação: 15/03/2005 Relator Antônio Carlos Bueno Ribeiro. Acórdão nº 202-16210.

. Ministério da Economia. Conselho Administrativo de Recursos Fiscais (CARF). Processo $n^{o}$ 10111.000229/2005-63. Data da Sessão 25/09/2018 Relatora Maria Aparecida Martins de Paula. Acórdão no 3402-005.586. 
. Ministério da Economia. Conselho Administrativo de Recursos Fiscais (CARF). Processo $n^{o}$ 10280.005071/2001-42. Data da Sessão 07/12/2015. Relator Rafael Vidal De Araujo. Acórdão nº 9101-002.146.

. Ministério da Economia. Conselho Administrativo de Recursos Fiscais (CARF). Processo $n^{\circ}$ 10940.900089/2006-43. Data da Sessão 18/03/2015 Relatora Irene Souza da Trindade Torres Oliveira. Acórdão nº 3202-001.608.

. Ministério da Economia. Conselho Administrativo de Recursos Fiscais (CARF). Processo $n^{o}$ 16327.002874/1999-71. Data da Sessão 05/12/2006 Relator Tarásio Campelo Borges. Acórdão no 303-33.805.

. Ministério da Economia. Conselho Administrativo de Recursos Fiscais (CARF). Processo $n^{o}$ 11080.729500/2013-23. Data da Sessão 18/04/2018 Relator Diego Diniz Ribeiro. Acórdão n ${ }^{\circ}$ 3402-005.145.

. Ministério da Economia. Conselho Administrativo de Recursos Fiscais (CARF). Processo $n^{o}$ 11634.720457/2011-65. Data da Sessão 14/04/2016 Relator Arlindo da Costa e Silva. Acórdão nº 2401-004.298.

. Ministério da Economia. Conselho Administrativo de Recursos Fiscais (CARF). Processo $n^{o}$ 12448.735359/2011-92. Data da Sessão 08/02/2017 Relator Carlos Henrique de Oliveira. Acórdão no 2201-003.425.

. Ministério da Economia. Conselho Administrativo de Recursos Fiscais (CARF). Processo $n^{o}$ 13889.000149/2004-24. Data da Sessão 22/08/2019 Relatora Maysa de Sá Pittondo Deligne. Acórdão nº 3402-006.834.

. Ministério da Economia. Conselho Administrativo de Recursos Fiscais (CARF). Processo $n^{o}$ 15956.720067/2012-94. Data da Sessão 02/12/2014 Relator Arlindo da Costa e Silva. Acórdão no 2302-003.516.

. Ministério da Economia. Conselho Administrativo de Recursos Fiscais (CARF). Processo $n^{o}$ 15983.000814/2009-41. Data da Sessão 23/07/2019. Redator Designado Mário Pereira de Pinho Filho. Acórdão no 9202-008.027.

. Ministério da Economia. Conselho Administrativo de Recursos Fiscais (CARF). Processo $n^{o}$ 13769.720304/2013-80. Data da Sessão 16/03/2017 Relator Marcelo Milton da Silva Risso. Acórdão n 2201-003.538.

. Ministério da Economia. Conselho Administrativo de Recursos Fiscais (CARF). Processo $n^{o}$ 10980.902100/2010-10. Sessão 24/09/2019 Relatora Maysa de Sá Pittondo Deligne. Acórdão no 3402-006.859.

. Ministério da Economia. Conselho Administrativo de Recursos Fiscais (CARF). Processo $n^{o}$ 11516.721501/2014-43. Sessão 23/02/2016. Relator Rosaldo Trevisan. Acórdão no 3401-003.096.

Ministério da Economia. Conselho Administrativo de Recursos Fiscais (CARF). Processo $n^{o}$ 13433.720026/2005-42. Sessão 19/06/2019 Relatora Maysa de Sá Pittondo Deligne. Acórdão no 3402-006.719. 
Ministério da Economia. Conselho Administrativo de Recursos Fiscais (CARF). Processo $n^{o}$ 19515.000528/2008-72. Sessão 28/09/2016 Relator Diego Diniz Ribeiro. Acórdão nº 3402-003.306.

Ministério da Economia. Conselho Administrativo de Recursos Fiscais (CARF). Súmula CARF $n^{o}$ 2. Ementa: O CARF não é competente para se pronunciar sobre a inconstitucionalidade de lei tributária. Acórdãos Precedentes: Acórdão no 101-94876, de 25/02/2005 Acórdão n ${ }^{\circ} 103-21568$, de 18/03/2004 Acórdão n ${ }^{\circ} 105-14586$, de 11/08/2004 Acórdão no 108-06035, de 14/03/2000 Acórdão n 102-46146, de 15/10/2003 Acórdão no 203-09298, de 05/11/2003 Acórdão no 201-77691, de 16/06/2004 Acórdão no 202-15674, de 06/07/2004 Acórdão no 201-78180, de 27/01/2005 Acórdão no 204-00115, de $17 / 05 / 2005$.

. Ministério da Economia. Conselho Administrativo de Recursos Fiscais (CARF). Institucional/Histórico dos Conselhos. Disponível em:

http://carf.fazenda.gov.br/sincon/public/pages/ConsultarInstitucional/Historico/HistoricoPo pup.jsf. Acesso: em 15 jul. 2019.

Ministério da Fazenda. Parecer Normativo COSIT n ${ }^{\circ}$ 2, de 23 de agosto de 2016. Assunto. Normas gerais de direito tributário. Diário Oficial da União, 24 ago. 2016. Disponível em:

http://normas.receita.fazenda.gov.br/sijut2consulta/link.action?visao=anotado\&idAto $=268$ 59. Acesso em: 7 dez. 2019.

. Ministério da Fazenda. Portaria MF no 341, de 12 de julho de 2011. Disciplina a constituição das Turmas e o funcionamento das Delegacias da Receita Federal do Brasil de Julgamento (DRJ). Diário Oficial da União, 14 jul. 2011. Disponível em:

http://normas.receita.fazenda.gov.br/sijut2consulta/link.action?visao=anotado\&idAto $=268$ 59. Acesso em: 7 dez. 2019.

. Ministério da Fazenda. Portaria MF no 343, de 9 de junho de 2015. Aprova o Regimento Interno do Conselho Administrativo de Recursos Fiscais (CARF) e dá outras providências. Diário Oficial da União, 10 jun. 2015. Disponível em:

http://normas.receita.fazenda.gov.br/sijut2consulta/link.action?visao=anotado\&idAto $=650$ 07. Acesso em: 7 dez. 2019.

Ministério da Fazenda. Trabalhos da comissão especial do código tributário nacional. Rio de Janeiro, 1954.

Procuradoria-Geral da Fazenda Nacional (PGFN). Portaria $n^{\circ} 820$ de 25 de outubro de 2004. Diário Oficial da União, 29 out. 2004. Disponível em: https://www.migalhas.com.br/dePeso/16,MI8528,81042-Portaria+n+820+da+PGFN. Acesso em: 7 dez. 2019

Receita Federal. Instrução Normativa RFB nº 1717, de 17 de julho de 2017. Estabelece normas sobre restituição, compensação, ressarcimento e reembolso, no âmbito da Secretaria da Receita Federal do Brasil. Diário Oficial da União, 18 jul. 2017. Disponível em: http://normas.receita.fazenda.gov.br/sijut2consulta/link.action?visao=anotado\&idAto $=845$ 03. Acesso em: 5 dez. 2019. 
. Receita Federal. Portaria PGFN n ${ }^{\circ} 742$, de 21 de dezembro de 2018. Disciplina, nos termos do art. 190 da Lei $n^{\circ} 13.105$, de 16 de março de 2015, e art. 19, § 13, da Lei ${ }^{\circ}$ 10.522, de 19 de julho de 2002, a celebração de negócio jurídico processual - NJP em sede de execução fiscal, para fins de equacionamento de débitos inscritos em dívida ativa da União e do FGTS, e dá outras providências. Diário Oficial da União, 28 dez. 2018.

Disponível em:

http://normas.receita.fazenda.gov.br/sijut2consulta/link.action?visao=anotado\&idAto $=977$ 57. Acesso em: 20 set. 2019.

. Superior Tribunal de Justiça (STJ). AgRg no REsp 1442087/MG, Relator Ministro Humberto Martins, Segunda Turma, julgado em 23/06/2015, DJe 30/06/2015.

. Superior Tribunal de Justiça (STJ). EREsp 609266/RS, 1ª. Seção, Relator Ministro Teori Albino Zavascki, julgado em 23/08/06, DJ 11/09/06.

. Superior Tribunal de Justiça (STJ). MS 009-DF. $1^{\mathrm{a}}$ Seção, Relator Ministro Pedro Acioli, DJ 18.12.89.

. Superior Tribunal de Justiça (STJ). MS 223-DF. $1^{\text {a }}$ Seção, Relator Ministro Garcia Vieira, DJU 16.04.90.

. Superior Tribunal de Justiça (STJ). MS 8.810/DF, Relator Ministro Humberto Gomes de Barros, Primeira Seção, julgado em 13/08/2003, DJ 06/10/2003.

. Superior Tribunal de Justiça (STJ). REsp 1130545/RJ, Relator Ministro Luiz Fux, Julgado em 09/08/2010, DJe 22/02/2011.

. Superior Tribunal de Justiça (STJ). REsp 1240691/RS, Relator Ministro Herman Benjamin, Segunda Turma, julgado em 20/04/2017, DJe 04/08/2017.

. Superior Tribunal de Justiça (STJ). REsp 759190/MT, Rel. Ministro Luiz Fux, Primeira Turma, julgado em 11/03/2008, DJe 23/04/2008.

. Superior Tribunal de Justiça (STJ). Súmula 633: “A Lei 9.784/1999, especialmente no que diz respeito ao prazo decadencial para a revisão de atos administrativos no âmbito da Administração Pública federal, pode ser aplicada, de forma subsidiária, aos estados e municípios, se inexistente norma local e específica que regule a matéria."

. Supremo Tribunal Federal (STF). ADI 1539, Relator Ministro Maurício Corrêa, Tribunal Pleno, julgado 24/04/2003, DJ 14/05/2003.

. Supremo Tribunal Federal (STF). AI 11227 Embargos, Relator Ministro Castro Nunes, Tribunal Pleno, julgado 05/06/1944, DJ 10/02/1945. p. 816.

. Supremo Tribunal Federal (STF). AI 791071 AgR-ED, Relator Ministro Dias

Toffoli, Primeira Turma, julgado 18/02/2014, DJE 18/03/2014.

. Supremo Tribunal Federal (STF). ARE 704846 ED, Relator Ministro Dias Toffoli, Primeira Turma, julgado 28/05/2013, DJE 08/08/2013. 
Supremo Tribunal Federal (STF). ARE 86.473, Relator Ministro Roberto Barroso, dec. monocrática, julgado em 9/02/2015, DJE 25/02/2015.

. Supremo Tribunal Federal (STF). MS 24268, Relatora Ministra Ellen Gracie, Relator para o Acórdão Min. Gilmar Mendes, Tribunal Pleno, julgado em 05/02/2004, DJ 17/09/2004.

Supremo Tribunal Federal (STF). RE 388359, Relator Ministro Marco Aurélio, Tribunal Pleno, julgado em 28/03/2007, DJe-042 publicado em 22/06/2007.

Supremo Tribunal Federal (STF). RE 594296, indicada no relatório apresentado pelo Ministro Dias Toffoli. Íntegra disponível em: http://redir.stf.jus.br/paginadorpub/paginador.jsp?docTP=TP\&docID=1729772. Acesso em: 2 set. 2019.

Supremo Tribunal Federal (STF). RE 594296, Relator Ministro Dias Toffoli, Tribunal Pleno, julgado em 21/09/2011, Repercussão Geral. DJe-030 Divulgado em 10/02/2012. Publicado em 13/02/2012.

Supremo Tribunal Federal (STF). RE 636941, Relator Ministro Luiz Fux, Tribunal Pleno, julgado em 13/02/2014, Acórdão Eletrônico Repercussão Geral - Mérito Publicado 04/04/2014.

Supremo Tribunal Federal (STF). RE 949297 RG, Relator Ministro Edson Fachin, julgado em 24/03/2016, DJe-097 13/05/2016). Pendente de julgamento conforme extrato de andamentos. Disponível em:

http://www.stf.jus.br/portal/jurisprudenciaRepercussao/verAndamentoProcesso.asp?incide nte $=4930112 \&$ numeroProcesso $=949297 \&$ classeProcesso $=R E \&$ numeroTema $=881$. Acesso em: 20 out. 2019.

Supremo Tribunal Federal (STF). Súmula $n^{\circ} 239$. Decisão que declara indevida a cobrança do imposto em determinado exercício não faz coisa julgada em relação aos posteriores. Brasília, DF: Supremo Tribunal Federal, [1963].

. Supremo Tribunal Federal (STF). Súmula $n^{\circ}$ 346. A Administração Pública pode declarar a nulidade dos seus próprios atos. Brasília, DF: Supremo Tribunal Federal, [1963].

Supremo Tribunal Federal (STF). Súmula $n^{\circ} 473$. A administração pode anular seus próprios atos, quando eivados de vícios que os tornam ilegais, porque deles não se originam direitos; ou revogá-los, por motivo de conveniência ou oportunidade, respeitados os direitos adquiridos, e ressalvada, em todos os casos, a apreciação judicial. Brasília, DF: Supremo Tribunal Federal, [1969].

Tribunal Federal de Recursos (TFR). MAS 72812/SP, $1^{\text {a }}$ Turma, DJ 14.11.74, Rel. Min. Moacir Catunda.

Tribunal Federal de Recursos (TFR). Súmula 227: Tributário. Revisão do lançamento. Inadmissibilidade. Mudança no critério jurídico. «A mudança de critério jurídico adotado pelo fisco não autoriza a revisão de lançamento.».

. Tribunal Regional Federal da $4^{\mathrm{a}}$ Região (TRF4). AC/MS 96041590-4/PR, $1^{\mathrm{a}}$ Turma, DJ 16.06.1999, Rel. Fernando Quadros da Silva. 
ESTADOS UNIDOS DA AMÉRICA. Administrative Procedure Act - APA. Disponível em: https://www.justice.gov/sites/default/files/jmd/legacy/2014/05/01/act-pl79-404.pdf. Acesso em: 25 ago. 2019.

FRANÇA. Conseil d'État. Les origines du Conseil d'État. Disponível em: https://www.conseil-etat.fr/le-conseil-d-etat/histoire-patrimoine/les-origines-du-conseil-detat. Acesso em: 13 jun. 2019.

MINAS GERAIS. Decreto-Lei $\mathrm{n}^{\circ} 1.618$, de 8 de janeiro de 1946. Dispõe sobre o julgamento administrativo das questões fiscais e dá outras providências. Diário Oficial, 8 jan. 1946. Disponível em:

http://www.fazenda.mg.gov.br/secretaria/conselho_contribuintes/amparo_legal/decreto_lei _\%201618.pdf. Acesso em: 6 dez. 2019.

SÃO PAULO (Estado). Decreto no 7.184, de 5 de junho de 1935. Cria o Tribunal de Impostos e Taxas e dá outras providências. Diário Oficial, 6 jun. 1935. Disponível em: https://www.al.sp.gov.br/repositorio/legislacao/decreto/1935/decreto-718405.06.1935.html. Acesso em: 6 dez. 2019. 